\title{
The Commercial Culpability Scale
}

\author{
David Morris Phillips $\dagger$
}

The Uniform Commercial Code is a labyrinth. The answer to most commercial problems may require not only fastidious attention to the language of the most relevant Code provision but also cross-references to other sections. Whether the commercial lawyer seeks to determine before a transaction who bears a particular risk, or after a failed transaction who must suffer the loss, the lawyer must tread the Code's terrain carefully, lest he err.

The lawyer's task would be made easier were there some pattern underlying the Code's allocation of risk of loss. Although such a pattern could not provide a definitive answer to particular problems, it would indicate generally who should bear a risk and thus help to insure that all relevant Code provisions have been considered. Knowledge of such a pattern would also facilitate interpretation of the relevant provisions. Not least of all, identifying a pattern would advance an intellectual understanding of the Code's goals and achievements, which in turn could aid its revision during changing times.

In this Article, I argue that the Code provisions evince a pattern that I term the "culpability scale." The culpability scale identifies a hierarchical set of rules to allocate loss. These rules are based upon the mental state, conduct, or position of the parties involved. Most culpable are those who violate the "intention principle": persons who intentionally create the event or situation that gives rise to possible loss by someone more innocent. If no one who intentionally created the loss-causing event can be discovered, loss is allocated based on a "knowledge principle" to that party who knew of the relevant circumstances. ${ }^{1}$ In the absence of a party with intent or knowledge, loss is allocated according to the "negligence principle" to that party who reasonably could have discovered the event or situation before acting or who otherwise failed to exercise due care. ${ }^{2} \mathrm{Fi}-$

$\dagger$ Professor of Law, Boston University. I wish to thank Bill Carney, Ron Cass, Clay Gillette, Neil Hecht, Thomas McCarthy, Mark Pettit, Dan Schaffer, Steve Schiffrin, Avi Soifer, and above all, John Leubsdorf, for helpful comments. I also wish to thank Paul Horn and Beverly Cohen for their research assistance.

1. A commercial actor frequently engages in more than one type of transaction. For example, one who deals in goods or commercial paper both buys and sells such items. As used in this Article, the knowledge principle is violated by an actor who knows of a defect when he acquires, uses, or sells an item.

2. The reader should note that violations of the negligence principle, as the term "negligence" is used in this Article, may not correspond with definitions of negligent conduct articulated outside the 
nally, if no greater level of culpability is present, the loss is distributed under the "strict liability principle" to that party who could have avoided the loss at least cost. ${ }^{3}$ Thus, for example, a party who is strictly liable could avoid liability by affirmatively proving that another party to the transaction was negligent, knowledgeable, or had intended the commercial loss. In the context of this Article, a commercial party has "violated" one of these principles when his mental state, conduct, or position is that defined by the corresponding principle. ${ }^{4}$

Code. For example, in United States v. Carroll Towing Co., 159 F.2d 169 (2d Cir. 1947), Judge Learned Hand articulated a standard of negligence dependent upon (i) the probability that the risk will materialize, (ii) the gravity of the resulting injury if the risk does materialize, and (iii) the burden of adequate precautions. Id. at 173. Judge Hand's definition of negligence, if unqualified, is broader than the range of conduct that the Code would term unreasonable and therefore negligent. Under the Code, a commercial actor might be negligent in failing to know of a fact when "from all the facts and circumstances known to him at the time in question he has reason to know that it exists," U.C.C. § 1$201(25)(c)$ (1977) [hereinafter cited without date unless citing other than 1977 version], but he would not be deemed negligent if he failed to search out facts unknown to him, even if the probability and gravity of harm were high and the burden of searching light. See, e.g., Eldon's Super Fresh Stores v. Merrill Lynch, Pierce, Fenner \& Smith, Inc., 296 Minn. 130, 137-38, 207 N.W.2d 282, 287-88 (1973) (because there is no duty to make inquiry, brokerage firm held not to have had "notice" of impropriety when it followed corporate accountant's instructions to credit to his personal trading account corporate check naming brokerage firm as payee). For the purposes of allocating loss under the Code, however, the commercial actor might still be responsible, but the grounds would be his violation of the strict liability principle. In any event, because the common law of negligence does not recognize a general duty to rescue, see, e.g., Buch v. Amory Mfg. Co., 69 N.H. 257, 261, 44 A. 809, 810-11 (1897), overruled on other grounds, Ouellette v. Blanchard, 116 N.H. 552, 557, 364 A.2d 631, 634 (1976); Yania v. Bigan, $397 \mathrm{~Pa}$. 316, 321-22, 155 A.2d 343, 346 (1959), and limits liability for conduct in other ways that might be deemed negligent under Judge Hand's formula, the inconsistency between negligence as generally understood and as used in this Article is probably not as great as Judge Hand's formula would suggest.

3. Findings of intent, knowledge, or negligence generally take account of the particular facts of each case. Allocation of loss according to the strict liability principle usually avoids such particularization, treating parties according to the class to which they belong. The strict liability principle is implicitly based upon a legislative calculation that, in general, parties of one class can avoid loss with less cost than parties within the adversary class. Courts usually do not attempt to test that judgment in individual cases. See Calabresi, Toward a Test for Strict Liability in Torts, 81 YALE L.J. 1055, 106770 (1972).

Reference to one who is the least costly loss avoider can have three meanings: first, the party in the best position to avoid loss; second, the party in the best position to distribute the loss; and third, the party in the best position to absorb the loss. The efficiency calculation that underlies the Code's culpability scale, including the strict liability principle, seems primarily based upon one's position to avoid loss, although absorption and distributional capabilities play a secondary role. See U.C.C. § 3405 comment 4.

Finally, the reader should note that a commercial actor's violation of the strict liability principle, which is based upon an efficiency calculation, does not necessarily imply that the commercial actor has acted inefficiently. The source of this distinction is the comparative nature of the judgment implicit in the strict liability principle. See infra p. 242. Thus, although some conduct that would come within the ambit of Judge Hand's formula, see supra note 2, would violate the strict liability principle, some conduct violating that principle would escape culpability according to Judge Hand's negligence formula.

4. This Article does not explore in depth two categories of cases: first, those where both commercial actors show the same level of culpability-for example, both are negligent-and second, those that involve exceptions to the culpability scale. Where both parties have been negligent, the text of the Code generally provides for the operation of a contributory negligence rule. See, e.g., U.C.C. \$§ 3$406,4-406$. Because of the same considerations that underlie the culpability scale, see infra pp. 251- 
Part I of this Article demonstrates that such a pattern of culpability exists in the Code. Part II explores the analytical foundations of the culpability scale in a commercial setting. These foundations include society's moral sense of degrees of wrongdoing, and the limitations of judicial process, particularly problems of proof. Above all, however, the explanation for the culpability scale lies in the instrumentalist notion that law is principally concerned with, and can affect, behavior. More specifically, Part II shows that allocation of loss according to the culpability scale serves to impose loss on the party whose conduct created the highest level of risk, the same party who with least cost could have avoided loss. Allocating loss to that party is then shown to be the most effective means of deterring loss-producing behavior. Hence, I conclude that the culpability scale is as concerned with prospective risk reduction as it is with loss allocation.

Part III of the Article distinguishes the prospective outlook of the culpability scale from the retrospective orientation of a system of liability based on causation. Finally, in Part IV, I seek to demonstrate that the use of the culpability scale to allocate risk in the Code was not accidental. The drafters of the Code were legal realists, who shared the prospective, riskoriented emphasis found in the culpability scale.

Recognition of the commercial culpability scale should prove important even to those who are not commercial lawyers. The Code's scheme for allocating loss is similar to systems of culpability generally recognized in other areas of substantive law, particularly torts ${ }^{5}$ and criminal law; ${ }^{6}$ therefore, this Article will serve to underscore the structural affinity of these seemingly disparate areas of legal study. By the same token, explanation of the Code's culpability scale should also help to explain why the law generally condemns certain behavior more than other behavior.

\section{Allocation of Loss According to the Culpability Scale}

The culpability scale pervades the Code's allocation of commercial risks. This Part demonstrates the scale's application to four common com-

63 , courts have a tendency to convert such contributory negligence rules into a comparative judgment regarding which of the two commercial parties was more negligent. See infra notes 62,136 . In other words, even where the Code's literal allocation of loss does not depend upon the relative culpability of two commercial actors, their relative culpability often does explain judicial interpretation and application of the relevant Code provisions and hence, the actual allocation of the loss between the actors. Exceptions to the culpability scale in the Code can probably be explained as instances where either the rationales for the culpability scale seem inapplicable or inquiry into the omitted level of culpability is especially difficult. See infra notes $18,31,142$. Both categories merit attention beyond that given in this Article.

5. Compare Restatement (SECOND) OF TORTS $\S \S 1-280$ (1964) ("Intentional Harms to Persons, Land, and Chattels") with id. $\S \S 281-503$ ("Negligence") and with jd. §§ 504-524A ("Strict Liability").

6. See MOdel PeNal CODE $\S 2.02$ (Proposed Official Draft 1962); infra pp. 286-87. 
mercial risks: fraud, forgery of signatures, flawed title or poor quality of goods, and mistaken reliance by multiple creditors on the same collateral.

\section{A. Risk of Fraud}

Loss resulting from fraud is governed in the Code by the "good faith purchase doctrine," which in general grants certain transferees ${ }^{7}$ better rights than their transferors had. ${ }^{8}$ The culpability scale can enhance our understanding of the rights of such transferees. ${ }^{9}$

Consider, for example, the good faith purchaser for value under article 2. Assume that an individual obtained goods through fraud from the original owner, promptly resold them to a good faith purchaser, and then disappeared with the proceeds, never to be seen again. The good faith purchaser would acquire title to the goods superior to the original owner only if the party who committed the fraud had "voidable title."10 The Code confers such title on a defrauding party when the original seller had intended to part voluntarily with his goods, even though the seller "was deceived as to the identity" of the transferor, "the delivery was in exchange for a check which is later dishonored," "it was agreed that the transaction was to be a "cash sale," " or "the delivery was procured through fraud punishable as larcenous under the criminal law."11

7. The favored transferee goes by several names in the Code. In article 2 (sales), he is a "good faith purchaser for value," U.C.C. \$ 2-403(1), or a "buyer in the ordinary course of business," id. \$ 2-403(2), (3); in article 3 (commercial paper), a "holder in due course," id. $\$ 3-305$; in article 5 (letters of credit), a "holder of the draft or demand ... under the credit and under circumstances which would make it a holder in due course," id. \$ 5-114(2)(a); in article 7 (documents of title), a "holder" to whom a negotiable document of title has been "duly negotiated," id. $\$ 7-501$ (4); in article 8 (securities), a "bona fide purchaser," id. § 8-302(1); and in article 9 (secured transactions), a purchaser who "gives value and receives delivery of the collateral without knowledge of the security interest and before it is perfected," id. $\S 9-301(1)$ (c), or a "buyer in ordinary course of business," id. $\S$ 9-307(3).

8. See generally Gilmore, The Commercial Doctrine of Good Faith Purchase, 63 YALE L.J. 1057 (1954) (discussing statutory and judicial trends in good faith purchase doctrine throughout commercial law) [hereinafter cited as Gilmore, Commercial Doctrine]. But see Gilmore, The Good Faith Purchase Idea and the Uniform Commercial Code: Confessions of a Repentant Draftsman, 15 GA. L. REV. 605 (1981) (later expression of skepticism about need for, and fairness of, good faith purchase doctrine).

9. One common explanation for the good faith purchase doctrine is a desire to promote ordinary course, as opposed to extraordinary, commercial transactions, by granting protections to purchasers who engage in the former. See Gilmore, Commercial Doctrine, supra note 8, at 1101. This explanation especially aids understanding of the rights of good faith purchasers who are holders to whom negotiable documents of title have been duly negotiated (in article 7) and buyers in the ordinary course of business (in articles 2, 7, and 9). The desire to promote ordinary course commercial transactions also helps to explain the existence of the good faith purchase doctrine in other contexts, but the ordinary-extraordinary distinction hardly clarifies the characteristics of the protected parties in these contexts.

10. U.C.C. $\S 2-403(1)$.

11. Id. The good faith purchaser does not have superior title over the original owner if the intermediary's title was void instead of voidable. The intermediary's title would be void, for example, if he had stolen the goods from the original owner.

One may wonder why the Code bothers to distinguish between "void" and "voidable" title. The 
Allocating loss according to status is characteristic of the strict liability principle. Inquiry into the individual characteristics of the commercial contestants is necessary only to determine if they belong to a certain class (such as owners or good faith purchasers); once that classification is accomplished, the strict liability approach becomes more abstract and less individualized. Such an approach implements a legislative calculation that, in general, parties within a certain class can more easily avoid loss than can members of the class to which their adversaries belong. ${ }^{12}$ In the case of the article 2 good faith purchaser, the Code assumes that, if the party who committed the fraud cannot be found, the original owner is, in general, the most efficient loss bearer. As the party on whom the primary fraud was perpetrated, the original owner presumably could have discovered the fraud more easily than the good faith purchaser. Even if one could demonstrate in a particular case that the good faith purchaser could have discovered the fraud more cheaply than the original owner, however, the good faith purchaser would still win under strict liability rules. The doctrine is a probability calculus, not an inquiry directed to the actual circumstances of the parties.

short answer is that the distinction is required by the possibility of separation between ownership and possession in the law. Presumably a person can sleep more soundly in the knowledge that even if he is deprived of possession by theft, his ownership interest (that is, his right to take possession upon finding that which has been taken) continues.

Yet this answer hardly provides a satisfactory explanation to the question of why the original owner enjoys superior rights, not only against the thief, but also against the good faith purchaser from the thief. The Code's resolution seems based upon the voluntary nature of the transaction by which the good faith purchaser obtained the goods. In contrast, the relationship between the original owner and the thief is involuntary. Because the former relationship is voluntary-that is, at least some dealing exists-the Code presumes that such a purchaser is a lower cost loss avoider than the original owner.

Section 2-403(2), (3) (the entrustment provision) confirms the nexus between the voluntariness of the transaction between original owner and wrongdoer and loss of ownership rights to a good faith purchaser. Entrustment of goods is another type of voluntary transaction; it is unlike a sale in that the transferee has possession but not title. Even though a party might take possession through fraud (by having possession but not title he would have the equivalent of "void" title), the good faith purchaser can still purchase the goods free and clear of the original owner's rights to them.

One possible criticism of the Code's exclusive emphasis upon voluntariness is that other factors are relevant to the determination of who can more easily avoid loss by theft. For example, the cost of protective measures to the original owner (backed up by theft insurance) seems far less on a per unit basis than the cost to a purchaser of verifying his transferor's title. Not surprisingly, the Code's resolution is not universally followed. See Explanatory Report on Draft Uniform Law on the Protection of Bona Fide Purchaser of Corporeal Movables 5-11 (1968) (describing various inroads on the right of original owner under European legal systems), reprinted in E. FARNSWORTH \& J. HONNOLD, CASES AND MATERIALS ON COMMERCIAL LAW 33-35 (3d ed. 1976).

The preceding discussion illustrates several difficulties with the Code's residual allocation of loss according to the strict liability principle. First, the efficiency calculation underlying a particular rule may be based upon an incomplete set of factors. Second, whether or not correctly formulated at its inception, the calculation can become dated over time, for example in the theft situation, as protective measures against burglary become more sophisticated and cheaper. Finally, the calculation underlying the strict liability principle is distinctively legislative; it is not made by judges according to the facts in individual cases. See supra note 3 . Hence, it is less flexible than judgments made on the basis of the intention, knowledge, or negligence principles.

12. See, e.g., U.C.C. $\$ \S 2-509$ comment 3, 3-405 comment 4. 
In contrast, allocation of loss according to the intention, knowledge, or negligence principles usually focuses attention on individual parties beyond those facts relevant to their class or status. ${ }^{13}$ Thus, the original owner of the goods may be able to shift the loss to an actor whose vice exceeded the owner's mere violation of the strict liability principle. The defrauding buyer, who has violated the intention principle, would, of course, be liable if the original owner could find him. ${ }^{14}$ Similarly, if the purchaser from the defrauding buyer knew of the fraud, his knowledge would negate his good faith. ${ }^{16} \mathrm{He}$ would only acquire his transferor's defective rights to the goods. In accordance with the knowledge principle, the purchaser, rather than the original owner, would ultimately bear the loss.

Frequently, the purchaser will be a "merchant," who is defined in article 2 as "a person who deals in goods of the kind or otherwise by his occupation holds himself out as having knowledge or skill peculiar to the practices or goods involved in the transaction ... "16 The good faith required of the merchant purchaser is not only "honesty in fact" but also "the observance of reasonable commercial standards of fair dealing in the trade"17 - an objective, negligence standard. The purchaser will be deemed to lack good faith if facts about the transferor's fraud abound, even if proof is lacking that the purchaser was aware of the fraud. ${ }^{18}$ In accord with the negligence principle, the purchaser will have acquired only his transferor's rights.

13. Instances in which individualization of parties is not important when applying the intention, knowledge, and negligence principles are rare, but they do occur. When the probability of violation of such principles is high, the Code (like other laws) sometimes draws a per se rule based upon the existence of intention, knowledge, or negligence, even though the relevant state of mind is not proved in the individual case. See infra pp. 248-50.

14. See J. WHITE \& R. SUMMERS, HANDBOOK OF THE LAW UNDER THE UNIFORM COMMERCIAL CODE $\S 3-11$, at 144 (2d ed. 1980).

15. The Code defines good faith as "honesty in fact in the conduct or transaction concerned." U.C.C. § 1-201(19); cf. Atlas Auto Rental Corp. v. Weisberg, 54 Misc. 2d 168, 281 N.Y.S.2d 400 (Civ. Ct. 1967) (original owner of two-year-old station wagon could recover judgment against junk dealer held to lack good faith because latter's purchase of vehicle from defrauder was for substantially less than readily apparent value).

16. U.C.C. $\S 2-104(1)$.

17. Id. § 2-103(1)(b).

18. See, e.g., Hollis v. Chamberlin, 243 Ark. 201, 419 S.W.2d 116 (1967) (dealer in used mobile homes and camper units who purchased camper unit that "looked new and was worth at least $\$ 1,000$ " for $\$ 500$ held not to be good faith purchaser); Atlas Auto Rental Corp. v. Weinberg, 54 Misc. 2d 168, 281 N.Y.S.2d 400 (Civ. Ct. 1967); $c$. Porter v. Wertz, 68 A.D. 2d 141, 416 N.Y.S.2d 254 (1979), aff', 53 N.Y.2d 696, 421 N.E.2d 500, 439 N.Y.S.2d 105 (1981) (art gallery that failed to inquire about ownership of painting held not to have purchased painting in good faith).

If the purchaser is not a merchant, one finds an exception to the culpability scale. The purchaser will win despite his negligence. Although a complete explanation for exceptions from the culpability scale is beyond the scope of this Article, see supra note 4, it seems difficult to settle upon a definition of "reasonable" conduct when an actor does not belong to a trade. Process difficulties might therefore offer an explanation for this exception. 
To summarize, if the defrauding party can be identified and found, liability will be imposed on him according to the intention principle. If not, the knowledge principle dictates that if another party knew of the fraud either when acquiring or transferring the goods, the loss will fall on him. If the purchaser is a merchant and if he has been negligent, the loss will next fall on him. Finally, in the absence of a finding of intent to defraud, knowledge, or negligence, the good faith purchase doctrine in article 2 generally places the loss upon the original owner. This allocation accords with the fourth element of the culpability scale, the strict liability principle. It is based on the belief that usually the original owner can avoid with least cost the loss that results from a fraud perpetrated upon him.

Consider next the Code's treatment of another good faith purchaser for value, the holder in due course of a negotiable instrument. Article 3 of the Code grants such a purchaser the possibility of acquiring better rights than his transferor held. ${ }^{19}$ Suppose, for example, that a seller fraudulently induces a buyer to purchase a machine on credit. At the time of purchase, the buyer makes a promissory note to the order of the seller payable one year from the date of the note. Before it is due, the seller negotiates the note to another party. On the due date, the new holder seeks to collect the note from its maker, the buyer. The buyer refuses to pay on the ground that the seller defrauded him.

Upon the buyer's dishonor, ${ }^{20}$ the holder would probably first seek to collect on the note from the seller. The seller would be liable both on his indorser's engagement to pay the instrument on dishonor ${ }^{21}$ and on his warranty to the holder that "no defense of any party ... [was] good against him." ${ }^{22}$ The fraudulent seller might in turn sue the buyer, based on the buyer's agreement, as maker, to pay the note. The seller's fraud, however, would provide the buyer with a successful defense, ${ }^{23}$ as would be expected under the intention principle.

If the seller could not be found, the holder would be likely to sue the buyer on his engagement as maker to pay the instrument. If the holder participated in the fraud on the buyer, the intention principle would dictate that the holder not recover. In fact, a court would find that the holder lacked good faith, defined as "honesty in fact in the conduct or transaction

19. See U.C.C. \$ 3-305.

20. Refusal to pay upon the holder's demand constitutes a dishonor. Id. § 3-507(1)(a).

21. See id. \$ 3-414(1).

22. Id. \& 3-417(2)(d).

23. The seller would not be a holder in due course because of his notice of a defense against a note. See id. \$§ 3-302(1)(c), 3-304(1)(b), 1-201(25)(a). Thus, the seller's rights on the instrument would be subject to "all defenses of [e.g., the maker-buyer] . . . which would be available in an action on a simple contract; and . . . the defenses of want or failure of consideration . . ." Id. $\S 3-306$ (b), (c). 
concerned."24 Lacking "good faith," the holder would not qualify as a holder in due course. ${ }^{25}$ Therefore, the buyer could assert the same defense of fraud against the holder that he could have asserted if the seller still held the note. ${ }^{28}$ If the holder did not participate in the fraud but knew of it when he acquired the note, he would again be deprived of holder in due course status-this time in accordance with the knowledge principle-under the rubric of "notice of any defense."27

Principles based upon intention and knowledge require a subjective determination of state of mind; the definition of notice, however, has an objective, as well as subjective, component. Thus, even when the holder did not know of the seller's fraud, he would still be held to have had "notice" of the buyer's defense if "from all the facts and circumstances known to him at the time in question" the holder had "reason to know" that the seller acquired the note in a fraudulent transaction. ${ }^{28}$ For example, the seller in the discussion above might have been disreputable, known to have defrauded many other buyers, and might have discounted the note to the holder at a small fraction of its face value. ${ }^{29}$ In this case, the holder would fail to qualify as a holder in due course, and would take the note subject to the buyer's defense based on the seller's fraud. This resolution, of course, accords with the negligence principle.

If the holder acquired the note for value neither knowledgeable of his transferor's fraud nor negligent in failing to discover it, he qualifies as a holder in due course and will be able to recover the amount of the note from its maker, the buyer. ${ }^{30}$ The strict liability principle applies here, as neither the holder nor the note's maker (the machine buyer) has violated the intention, knowledge, or negligence principles. As between the maker

24. Id. § 1-201(19).

25. Id. $\S 3-302(1)(b)$; see Thompson v. First Nat'l Bank \& Trust Co., 142 Ga. App. 174, 235 S.E.2d 582 (1977) (bank whose officer made fraudulent misrepresentations to stock purchaser did not take note in good faith and hence is not holder in due course); $c f$. Frye v. Farmers \& Merchants Bank, 561 S.W.2d 392 (Mo. Ct. App. 1977) (bank held to have lacked "good faith" where it knew that the note was a personal obligation of the corporation's president not to be paid with corporate funds).

26. See U.C.C. § 3-306(b), (c).

27. See id. $\S 3-302(1)(c)$.

28. Section 1-201(25) states in part that "[a] person has 'notice' of a fact when (a) he has actual knowledge of it; or (b) he has received a notice or notification of it; or (c) from all the facts and circumstances known to him at the time in question he has reason to know that it exists."

29. See, e.g., Stewart v. Thornton, 116 Ariz. 107, 568 P.2d 414 (1977) (buyer of note, executed as part of land purchase, at one-third of note's face value within 48 hours after purchase, when purchase was subject to right of rescission within 48 hours, had sufficient notice of fraud to lose holder in due course status); Hollis v. Chamberlin, 243 Ark. 201, 419 S.W.2d 116 (1967) (buyer who purchased camper at one-half of market value and asked no questions about seller's title was not innocent purchaser).

30. The holder would attain his rights under $\S 3-305$ rather than $\S 3-306$. Under $\S 3-305$, the holder in due course generally "takes the instrument free from . . . (2) all defenses of any party to the instrument with whom the holder has not dealt . . .." 
of a note and a holder in due course, the maker seems to be the party able to avoid the loss at least cost. The fraud occurred between the maker and the seller; therefore, the maker's proximity to the fraudulent conduct would ordinarily imply that he need expend fewer resources to avoid the loss than the holder would have had to expend to discover the seller's fraud on the maker. ${ }^{31}$

\section{B. Forgery of Signatures on Instruments and Documents}

A major risk accompanying the use of instruments and documents is forgery. The Code allocates losses from forgeries by means of implied warranty, principal-agency, and holder in due course doctrines. As we observed in the previous section, however, these doctrines only mask the operation of the culpability scale.

To illustrate, suppose that $F$ forges $A$ 's signature, as drawer, on a check drawn on Bank 1, the drawee or payor bank, ${ }^{32}$ payable to the order of $P$. $P$ deposits the check in its bank, Bank 2, which is denominated a depository $^{33}$ and collecting ${ }^{34}$ bank. Bank 2 forwards the check to Bank 1, which pays the check. $A$ compels Bank 1 to recredit $A$ 's account in the amount of the forged check. Bank 1, consequently, seeks to recover its loss. If Bank 1 can locate $F$, it can impose liability on him. $F$ will have breached the warranty that he had "no knowledge that the signature of the maker or drawer is unauthorized ...."ss Alternatively, Bank 1 could sue $F$ on grounds of fraud, since nothing in the Code displaces that common law cause of action. ${ }^{38}$ Whether the doctrinal language is phrased in terms of

31. A major inroad against the holder in due course doctrine has been made in the context of consumer transactions, where the judgment about the relative abilities of buyers and holders to avoid loss is quite problematic. See Unico v. Owen, 50 N.J. 101, 232 A.2d 405 (1967) (financing company established to discount consumer installment contracts and notes payable to merchants held not to be holder in due course); UNIF. CONSUMER CREDIT CODE $\S 3.404(1)$ (1974) (with respect to consumer credit sale "an assignee of the rights of the seller . . . is subject to all claims and defenses of the consumer against the seller . . . notwithstanding that the assignee is a holder in due course . . ..").

The Unico court justified this inroad by arguing that as between the defrauded buyer and the financing company suing as an asserted holder in due course, the latter could, with lower cost, protect against the risk of a seller's inability to perform. 50 N.J. at 109-10, 232 A.2d at 410 .

32. For the definition of "payor bank," see U.C.C. § 4-105(b). Although the term "payor bank" is used in article 4 of the Code and the term "drawee" is used in article 3 , the two terms are interchangeable in the case of a check, which the Code defines as "a draft drawn on a bank and payable on demand." Id. § 3-104(2)(b).

33. See id. \$ 4-105(a) (defining depository bank).

34. See id. \$ 4-105(d) (defining collecting bank).

35. Id. $\S 3-417(1)$ (b). Although $\S 3-417$ (1) is ordinarily not used by the payor bank against the drawer or maker of an instrument, it is only because the drawer and payor bank normally have a preexisting contractual relationship. As a prior transferor of the check, as well as its drawer, $F$ will have given the warranties discussed in $\$ 3-417(1)$.

36. Section 1-103 of the Code states that "[u]nless displaced by the particular provisions of this Act, the principles of law and equity, including the law merchant and the law relative to capacity to contract, principal and agent, estoppel, fraud, misrepresentation, duress, coercion, mistake, bankruptcy, or other validating or invalidating cause shall supplement its provisions." 
fraud or warranty, $F$ 's primary liability is an application of the intention principle.

The intention principle would similarly dictate that $F$ be held ultimately liable if Bank 1 had recognized the forgery and dishonored the instrument. Bank 2 would then have charged back the amount of the check to $P$ 's account and returned the check to $P .^{37}$ If $P$ could find $F, P$ could recover either for breach of $F$ 's warranty to $P$ that all signatures were genuine and authorized ${ }^{38}$ or for breach of the drawer's contract, made by $F$, to pay the instrument upon dishonor ${ }^{39} F$ will be held to have made that contract with subsequent parties because $F$ 's forgery, although it does not operate as $A$ 's signature, does count as $F^{\prime}$ 's own signature. ${ }^{40}$

It is likely, however, that $F$ will not be found and that another party must bear the loss. If $P$ knew of the forgery at any time before collection and payment of the check, he will bear the risk of loss. If Bank 1 had dishonored the check, Bank 2 would simply have charged back the amount of the check to $P$ 's account. ${ }^{41}$ If $P$ did not have an account with Bank 2-the transaction between them being in the nature of a purchase by Bank 2 from $P$ rather than a collection on the instrument by Bank 2 on behalf of $P$-Bank 2 could still transfer the loss to $P$ on several theories. As an indorser, $P$ had contracted to pay the instrument upon dishonor. ${ }^{42} P$ also had made a transfer warranty that "all signatures are genuine or authorized." 43

If Bank 1 had mistakenly paid rather than dishonored the check, it could seek redress from $P$ if it could prove that $P$ breached the presentment warranty that he "ha[d] no knowledge that the signature of the maker or drawer . . . [was] unauthorized." 44 Thus, where $P$ discovered and knew of $F$ 's forgery before seeking payment on the check, the loss would fall on $P$ whether or not the check was honored. These results accord with the culpability scale: If the intention principle is unhelpful because the party who created the loss cannot be sued, loss should be allocated according to the knowledge principle.

It is more likely, however, that $P$ does not know of $F$ 's forgery; presum-

37. See U.C.C. $\$ 4-212(1)$. The theoretical basis of article 4's charge-back provision is the principal-agent relationship between the depositor and the depository-collecting bank, which continues until final settlement is received by the latter. See id. $\S 4-201$ comment 4 . If final payment is never made and therefore, final settlement is never received, any loss remains with the principal, the depositor $P$. See id. $\S \S 4-201(1)$ \& comments 1-7, 4-212 comment 3.

38. See id. § 3-417(2)(b).

39. See id. \$ 3-413(2).

40. See id. § 3-404.

41. See id. § 4-212(1).

42. See id. § 3-414(1).

43. Id. $\S 3-417(2)(\mathrm{b})$.

44. Id. $\S \S 3-417(1)(\mathrm{b}), 4-207(1)(\mathrm{b})$. 
ably $P$ would not give $F$ value for an instrument laden with trouble, including possible litigation. Nor would $F$ be likely to inform $P$ that $P$ has paid value for a forged check, which necessarily carries a higher risk of dishonor than most checks. If, then, allocation of loss according to the intention or knowledge principles is impractical (because $F$ has absconded) or irrelevant (because no party who acted knowingly can be identified), the culpability scale would call for allocation of loss according to the negligence principle.

$A$, the supposed drawer whose signature has been forged, may have been negligent, for example, by not protecting a signature stamp from discovery and theft by others ${ }^{45}$ or by signing blank checks that were left unattended. ${ }^{46}$ If Bank 1 dishonored the check, Bank 2 could have charged back the amount of the check and returned it to $P{ }^{47} P$ could then sue $A$ on the drawer's contract to pay the check upon dishonor. ${ }^{18}$ Although $A$ could argue that $F$ actually drew the check, $A$ 's defense would fail under the Code if "his negligence substantially contribute[d] . . . to the making of an unauthorized signature." 49 If, instead of dishonoring the check, Bank 1 had paid the check and debited $A$ 's account, Bank 1 could contend that its action was proper on the same theory. ${ }^{50}$

Alternatively, $P$ rather than $A$ may have acted negligently. Assume that Bank 1 honored the check and then sought reimbursement from $P$. The Code would protect the individual in $P$ 's position who was either a holder in due course or "a person who has in good faith changed his position in reliance on the payment"s1 - in those cases, payment by Bank 1 would be considered "final."

45. See id. $\$ 3-406$ comment 7 .

46. See Herdman v. First Nat'l City Bank, 3 U.C.C. Rep. Serv. 628 (N.Y. App. Term 1966) (where plaintiff-drawer allegedly signed check but left it made out in blank in desk drawer, majority held plaintif's negligence is triable question of fact, while dissent would grant summary judgment for defendant bank that paid check).

47. See U.C.C. § 4-212(1).

48. See id. $\S 3-413(2)$.

49. Id. § 3.406; cf. Dominion Constr., Inc. v. First Nat'l Bank, 271 Md. 154, 315 A.2d 69 (1974) (drawer negligently and substantially contributed to forged endorsement by failing to identify intended payees as corporations, to advise drawee bank of "joint pay agreement," and to draw check so as to make it properly payable to joint payees); see also U.C.C. \$ 3-404(1) comment 4 (recognizing possibility that negligence precludes drawer from denying signature).

50. See U.C.C. \$ 3-406; cf. Thompson Maple Prods., Inc. v. Citizens Nat'l Bank, 211 Pa. Super. 42,234 A.2d 32 (1967) (drawer, which manufactured bowling pin "blanks" from logs, had no right to recredit where forgery of payees' signatures facilitated by its practice of leaving blank scaling slips (basis for securing payments for logs delivered to drawer) unattended in company premises and entrusting checks to forger for redelivery to intended payees).

51. U.C.C. § 3-418.

52. See id. The final payment rule holds that "a drawee who accepts or pays an instrument on which the signature of the drawer is forged is bound on his acceptance and cannot recover back his payment." Id. \$ $3-418$ comment 1 . The finality principle first appeared in Price v. Neal, 3 Burr. 1354, 97 Eng. Rep. 871 (K.B. 1762). 
know" of the forgery of $A$ 's signature, $P$ would be considered to have had notice of a defense ${ }^{63}$ to the instrument and hence would fail to qualify as a holder in due course. ${ }^{54}$ And while it would be possible for $P$ to escape liability by showing reliance, such a course is difficult. ${ }^{5 s} P$ would likely fail on both counts, in which case the Code would relegate the problem of Bank 1's right to recover against $P$ to law outside the Code. ${ }^{56}$ In most cases, Bank 1 would win, since it could rescind the transaction with $P$ based on their mutual mistake of fact about the authenticity of the drawer's signature. ${ }^{57}$ The result would be the same if Bank 1 dishonored the check. In that case, Bank 2 would debit $P$ 's account by the amount of the check. ${ }^{88} P$ would be unable to shift the loss elsewhere.

The last party whose possible negligence should be considered is Bank 1, the payor bank, which may have acted negligently when it honored the forged check. ${ }^{69}$ Under most circumstances the payor bank cannot easily shift to another the loss resulting from having honored a check on which the drawer's signature has been forged. ${ }^{60}$ If Bank 1 is deemed to have failed to exercise reasonable care when honoring the check, its task of transferring the loss elsewhere is made even more difficult. ${ }^{61}$ To sum up,

\author{
53. See U.C.C. $\S \S 1-201(25), 3-304(1)(a)$. \\ 54. See id. $\S 3-302(1)(c)$. \\ 55. See First Nat'l City Bank v. Altman, 3 U.C.C. Rep. Serv. 815 (N.Y. Sup. Ct. 1966), affd
} mem., 27 A.D.2d 706, 277 N.Y.S.2d 813 (1967) (with respect to two checks given as payment for two envelopes of diamonds, payee diamond dealer held to have relied on payment as to one envelope where payee verified that check had been paid before turning over diamonds, but not as to payment for other envelope, where payee did not so verify).

56. The common law action would be allowed pursuant to U.C.C. § 1-103. See J. WHITE \& R. SUMAERS, supra note $14, \S 16-2$, at 609 .

57. Cf. Smith v. Zimbalist, 2 Cal. App. 2d 324, 38 P.2d 170 (1934) (sale of two violins voidable where both seller and buyer mistakenly believed one violin to be a Stradivarius and other a Guarnerius); Sherwood v. Walker, 66 Mich. 568, 33 N.W. 919 (1887) (rescission of sale of cow granted where both seller and buyer mistakenly believed cow to be barren); RESTATEMENT (SECOND) OF CONTRACTS $\S \S 152-154$ (1979) (rules governing mistake by one or both parties).

White and Summers would disagree with my discussion of forged checks on the ground that $\S 3-$ 418 must be read in conjunction with $\S 4-213$, which relates to final payment, and $\S 4-302$, which relates to the accountability of payor banks. Unlike $\S 3-418$, neither $\S 4-213$ nor $\$ 4-302$ is conditioned on the recipient of the payment being a holder in due course or one who has changed his position in good faith reliance upon the payment. See J. WHITE \& R. SUMMERS, supra note 14, § 162 , at 613-18. However, their analysis seems faulty on at least two grounds. First, it would require distinguishing between those rules applicable to checks (as to which both articles 3 and 4 apply) and those applicable to other negotiable instruments (as to which article 3 applies), without substantiating this distinction on policy grounds. Second, it would on occasion upset the culpability scale and result in the less culpable party (here, the payor bank) bearing the loss. The alternative to White and Summers' suggested resolution is to read $\$ \S 4-213$ and 4-302 in light of $\$ 3-418$. Not surprisingly, the case law does not consistently support White and Summers' position (as they admit, id. at 616). See First Nat'l City Bank v. Altman, 3 U.C.C. Rep. Serv. 815 (N.Y. Sup. Ct. 1966), aff'd mem., 27 A.D.2d 706, 277 N.Y.S.2d 813 (1967).

58. See U.C.C. $\S 4-212(1)$.

59. By definition, a payor bank is not negligent if it discovers forgery and dishonors a check.

60. See infra pp. 241-42.

61. See U.C.C. $\S \S 3-406$ (bank must have paid "in accordance with the reasonable commercial standards of the drawee's or payor's business" even to assert the negligence of other parties), 4-406(3) 
if either $A, P$, or Bank 1 failed to act reasonably to avoid the risk, that party will bear the loss, provided only that the other contestants have not acted intentionally, knowingly, or negligently. The negligence principle operates in the absence of facts or circumstances that would make the intention or knowledge principles applicable. ${ }^{62}$

(customer's failure to comply with reasonable care requirements of $\S 4-406$ no bar to his recovery where he can establish lack of ordinary care on part of payor bank); cf. Jackson v. First Nat'l Bank, 55 Tenn. App. 545, 403 S.W.2d 109 (1966) (payor bank must bear loss on checks drawn on church's account where bank negligently failed to note and inquire about fact that checks were indorsed by a dog racing track and that checks were made out to church secretary personally, who was the forger).

62. One of the most difficult problems the Code's drafters encountered was deciding how to allocate losses when both parties violated the same culpability principle. That situation is most apt to occur when both contesting parties have violated the negligence principle. The drafters were most explicit about this problem in the context of articles 3 and 4.

The primary section that allocates loss in the event of a violation of the negligence principle in article 3 is $\S 3-406$, which states:

Any person who by his negligence substantially contributes to a material alteration of the instrument or to the making of an unauthorized signature is precluded from asserting the alteration or lack of authority against a holder in due course or against a drawee or other payor who pays the instrument in good faith and in accordance with the reasonable commercial standards of the drawee's or other payor's business.

Quite patently, § 3-406 incorporates a contributory negligence scheme. If the payor acted reasonably, but its commercial adversary did not, the latter party is precluded from asserting the forgery or alteration against the payor. But if both have been negligent, the other party may still assert the alteration or forgery against the payor. And most significantly, this result seems to hold even when the other party is more negligent than the payor. See also U.C.C. \$ 4-406(3) (drawer who is negligent in reporting forgeries or alterations to payor bank can nevertheless compel recredit to his account "if the customer establishes lack of ordinary care on the part of the bank in paying the item(s)").

Because $\$ \S 3-406$ and 4-406 incorporate a contributory negligence standard rather than an allocative scheme placing the entire loss on the more negligent of the two actors, they manifest a departure from the culpability scale. Yet despite the language of the Code, courts have shown a tendency to erect a culpability scale in this context by imposing the loss on the more negligent party. One means of doing so is to read those sections, contrary to their apparent meaning, as incorporating a comparative negligence standard. Another means is to interpret the reasonableness of the payor's conduct in light of its adversary's conduct, and consequently to declare reasonable that which under most other circumstances would not be considered so.

Consider, for example, Jacoby Transp. Sys. v. Continental Bank, 28 U.C.C. Rep. Serv. 1398 (Pa. Super. Ct. 1980). There the drawer, Jacoby Transport, sued the payor bank for honoring 38 unsigned checks. The signature card on file required that Jacoby's checks be signed by at least one of three individuals: Harold Burgher, the drawer's principal owner, or one of his two sons. The bank admitted that because of the volume of checks processed, it did not examine checks drawn on the bank for facial regularity. Yet despite this admission, there seems little doubt that Jacoby Transport was the more negligent party. Jacoby Transport had ordered the checks printed with its full corporate name but excluding any signature lines for personal signatures. Burgher had delivered the checks, each postdated with a different date, to the payee for subsequent use by the payee. The payee, upon delivering title to certain trucking equipment to Jacoby, was to get Burgher's signature on the checks and then cash them. The payee's practice of depositing and collecting the checks without getting Burgher's signature became known to Burgher some time before he notified the payor bank. In fact, Jacoby's bookkeeper did not bother to look at the checks for a period of three weeks following their return, despite a warning on the returned checks that immediate attention was necessary. Id. at 1401.

In this situation, it seems clear that Jacoby Transport rather than the bank should have borne the loss if the basis of the normative judgment was the relative culpability of the parties. On the other hand, it seems equally clear that the payor bank rather than Jacoby Transport should have borne the loss if the basis of the judgment was statutory language. Id. at 1405. The court came close to admitting that its holding was based on a comparative culpability view:

[I]n our opinion the definition of "reasonable business standards" should not be formulated in so one-sided a way. Even a bank is entitled to expect some degree of prudence on the part of 
If no one can be proved to have acted negligently, either $P$ or Bank 1 must bear the loss. If Bank 1 has dishonored the check, $P$ will bear the loss. Even if $P$ had transferred the check to another party prior to its deposit, collection, and payment, he would be liable on the theory that he had breached the transfer warranty that "all signatures are genuine or authorized." ${ }^{\circ 3}$ Although this language speaks only in terms of implied warranty, allocating the loss to $P$ manifests the operation of the strict liability principle. $P$ took the check from the forger. Thus, where $P$ can find no party who has violated the intention, knowledge, or negligence principles, $P$ is deemed to be that party who with least cost could have avoided the loss. It is again important to note that this judgment is based not on the particular facts about $P$, but on his position. It does not matter whether $P$ dealt with the forger once or many times.

If Bank 1 has honored the check, it will bear the loss rather than $P$. The legal rationale for this result is that payment is final. ${ }^{84}$ Bank 1 cannot upset the finality of payment on a breach of warranty theory because a prior transferor only warrants to the payor that he had "no knowledge that the signature of the . . drawer [was] unauthorized." Bank 1 charge $A$ 's account, because the check, lacking $A$ 's signature, is clearly not "properly payable."

Bank 1's role as the residual loss bearer, when it has honored a check with a forged drawer's signature, again reflects an efficiency calculation. This calculation assumes that Bank 1 can avoid the loss with less cost

its customer. Here appellant exhibited no prudence at all; it knew at least as early as December that Slater [the payee] had negotiated one of the unsigned checks, and with very little effort, could have precluded any negotiation of the outstanding checks.

Id. at 1406.

Similar results have been reached by other courts. See J. Gordon Neeley Enters. v. American Nat'l Bank, 403 So. 2d 887 (Ala. 1981); K \& K Mfg. v. Union Bank, 31 U.C.C. Rep. Serv. 177 (Ariz. 1981); Hartford Accident \& Indem. Co. v. Dean's Shop-Rite, Inc., 48 N.C. App. 615,269 S.E.2d 282 (1980).

Allocating the loss to the more negligent of the commercial adversaries becomes easier when $\S \S 3-$ 406 and 4-406 do not govern the fact situation. See Cooper v. Union Bank, 9 Cal. 3d 371, 507 P.2d 609, 107 Cal. Rptr. 1 (1973).

63. U.C.C. $\S 3-417(2)(\mathrm{b})$.

64. See id. § 3-418; supra note 52; see also Mortimer Agency, Inc. v. Underwriter's Trust Co., 73 Misc. 2d 970, 341 N.Y.S.2d 75 (Civ. Ct. 1973) (payor bank must bear loss where it first certified and then paid check stolen from supposed drawer and signed with rubber stamp that drawer had never used on checks).

65. U.C.C. $\$ \S 3-417(1)(b), 4-207(1)(b)$ (emphasis added); see Dozier v. First Ala. Bank, 363 So. 2d 781, 784 (Ala. Civ. App. 1978) (payor bank had no right to pursue endorser on breach of warranty theory where evidence was lacking that endorser knew that person who signed corporate check was not authorized to do so); Payroll Check Cashing v. New Palestine Bank, 401 N.E.2d 752 (Ind. Ct. App. 1980) (payor bank cannot recover amount of three checks from check cashing service that cashed checks for payee where there was no proof that check cashing service knew drawer's signature was forged).

66. U.C.C. § 4-401(1); see Mortimer Agency, Inc. v. Underwriter's Trust Co., 73 Misc. 2d 970, 341 N.Y.S.2d 75 (Civ. Ct. 1973). 
than $P$ because a payor bank has a copy of the drawer's signature in its possession, while payees, as a rule, do not. $F$ 's forgery may have been so masterful that a reasonably skilled bank employee could not have detected it even if he checked the signature card. ${ }^{67}$ Or $P$ might have dealt with $F$ on several occasions or had occasion to see $A$ 's signature. Nonetheless, unless $P$ acted negligently (or worse), Bank 1 will bear the loss if it honored the check. The strict liability principle allocates loss on the basis of position rather than on such particular facts.

Bank 1 might dispute the efficiency calculation behind the strict liability rule. The bank might claim that checking each drawer's signature card would slow the payment process excessively, given the large volume of small checks it handles. ${ }^{68}$ In other words, it would claim that the cost of prevention would exceed the losses prevented. The allocation of risk, however, is based not only on assumptions about group, rather than individual, behavior, but also on a comparative analysis of costs. The position of the payor bank is compared with the position of other potential residuaries of loss such as the depository bank. If it is inefficient for payor banks generally to check signature cards, it would be even more inefficient for depository banks to check the authenticity of drawers' signatures since they lack the signature cards to do so. In sum, the judgment that it is inefficient for anyone to avoid the loss in this setting, even where such loss avoidance surely would be desirable in a costless world, cannot be tested unless the loss is assessed to the least costly risk bearer. ${ }^{69}$

Now suppose that $F$ forges the payee's signature as an indorsement on a check validly signed by the drawer. In this case, liability shifts away

67. Cf. First Nat'l Bank \& Trust Co. v. Cutright, 189 Neb. 805, 807-08, 205 N.W.2d 542, 544 (1973) (payor bank negligent despite fact that check signed with rubber stamp facsimile of drawer's signature and evidence that "[t]he difficulty of detecting unauthorized signatures increased with the introduction of pens with felt tips which widened the lines").

68. See id. at 810,205 N.W.2d at 545 (noting high cost of comparing signatures); Jackson v. First Nat'l Bank, 55 Tenn. App. 545, 553, 403 S.W.2d 109, 113 (1966) (rejecting as matter of law payor bank's argument that close examination of signature cards not practical under "modern banking practices"); Penney, Bank Statements, Cancelled Checks, and Article Four in the Electronic Age, 65 MICH. L. REV. 1341, 1360 (1967). Because this argument applies to the conduct of payor banks in relation to checks of small amounts generally, it pertains to the "position" of payor banks. If this argument is true, society may not really prefer payor banks to take steps to minimize losses.

69. White and Summers seem to have completely missed this point:

If Price v. Neal is founded on the theory that any drawee who fails to discover a forged drawer's signature is negligent and thus is not entitled to recover payment, there should be an exception to the doctrine for those cases in which the signature is so cleverly forged that a banking employee using due care could not discover the forgery. If on the other hand, the rule is premised on the desirability of ending and not reopening commercial transactions, then the same rule should apply to forged indorsement cases as well as forged drawer cases. We can discern no adequate rationale to explain the difference between the liability of the drawee bank on checks bearing forged indorsements and its liability on those bearing forged drawer's signatures.

J. WHITE \& R. SUMMERS, supra note $14, \S 16-2$, at 610. 
from the payor bank, Bank 1. If none of the parties contesting allocation of loss acted intentionally, knowingly, or negligently, the loss would be thrown on the party who took from $F$, under the legal theory that this party gave and breached the warranty that it "ha[d] good title to the instrument."70 Thus, if $F$ forged $P$ 's signature, deposited the check, and received credit from Bank 2, that bank would bear the loss. ${ }^{71}$ If another party intervened between $F$ and Bank 2, the loss bearer would be that party. ${ }^{72}$

Again, the legal theory here masks an efficiency calculation. Bank 1 knows the drawer's signature, but not the payee's. Therefore it cannot be concluded, a priori, that Bank 1 has superior ability to avoid the loss. We are thrown back to the judgment that generally the party who takes from the forger can avoid loss with least cost.

The generalized nature of this judgment merits repetition. Bank 2 may never have seen $F$ or $P$ before; Bank 1 might have occasionally transacted business with either or both of them. Nevertheless, absent a finding of Bank 1's negligence, Bank 2 must bear the loss. The strict liability principle does not operate on the basis of particularities beyond Bank 2's and Bank 1's respective positions, the former as a depository bank that dealt with the forger and the latter as a payor bank further removed from the forger. Within this framework, the culpability scale makes a comparative, rather than absolute, judgment about loss avoidance.

\section{Risks of Flawed Title and Poor Quality}

Allocation of loss resulting from the sale of defective goods presents another test of the pervasiveness of the culpability scale. Liability for breach of the warranty provisions in article 2 of the Code ${ }^{73}$ is commonly considered to be the contractual analogue to strict liability in tort. ${ }^{74}$ One might

70. U.C.C. $\S \S 3-417(1)(a),(2)(a), 4-207(1)(a),(2)(a)$.

71. See id. \$§ 3-417(1)(a), 4-207(1)(a); Twellman v. Lindell Trust Co., 534 S.W.2d 83 (Mo. Ct. App. 1976) (collecting bank held liable to drawer-payor in third party action brought against drawerpayor's bank for amount of treasurer's check with forged payee's signature). Compare U.C.C. §§ 4$207(1)(a), 3-417(1)(a)$ (warranty of good title) with id. \$\$ 4-207(1)(b), 3-417(1)(b) (warranty concerning unauthorized drawer's signature). The good title warranty is absolute, while the warranty concerning the authority of the drawer's signature depends upon the presenter's state of knowledge. Bank 2 will have breached the good title warranty because $F$ 's signature cannot substitute for $P$ 's signature, id. \$ 3-404, and the latter is necessary to enable Bank 2 to become a holder. See id. $\S \S 1$ 201(20), 3-202(1), (2). In this context, being a holder is synonymous with having good title. $P$ would have a cause of action against Bank 2 for conversion. See id. \$ 3-419; Cooper v. Union Bank, 9 Cal. 3d 371, 507 P.2d 609, 107 Cal. Rptr. 1 (1973).

72. See U.C.C. $\$ \S 3-417(2)(a),(b), 4-207(2)(a)$, (b).

73. Id. $\S \S 2-312$ to $2-318$.

74. Compare Henningsen v. Bloomfield Motors, Inc., 32 N.J. 358, 370-84, 161 A.2d 69, 76-84 (1960) (consumer's remedy against manufacturer based on implied warranty theory) with Greenman v. Yuba Power Prods., Inc., 59 Cal. 2d 57, 377 P.2d 897, 27 Cal. Rptr. 697 (1963) (finding for buyer despite buyer's failure to give timely notice of warranty claim, rejecting warranty terminology in favor 
therefore conclude that this area is governed exclusively by the strict liability component of the culpability scale. My claim here is not that allocation of loss for breach of warranties will always incorporate all of the culpability scale, either as a matter of statutory design or judicial resolution. Rather, I claim that strong evidence of the culpability scale pervades even this area of risk allocation, commonly considered to lack any such scale at all.

Article 2's warranty provisions do reflect, in the main, the efficiency calculation underlying the strict liability principle. For example, the seller is closer than any other party to situations that would raise questions about good title. Any search of title by the buyer must include inquiry into the seller's authority to sell. The seller starts out with that knowledge and therefore need expend resources only to check the authority of prior parties in the chain of distribution. Accordingly, section 2-312 provides that the seller warrants to the buyer that "the title conveyed shall be good, and its transfer rightful." 78

Similarly, the Gode assumes that the seller is the party who may avoid product defects at least cost. $^{76}$ Where the seller is a manufacturer, the manufacturing process is under his control, not the buyer's. Even if the seller is not a manufacturer, he is closer to the manufacturer and, therefore, potentially can exert a greater influence on the manufacturer's behavior than can the seller's ultimate customer. In addition, the seller usually enjoys superior opportunities to test the product because the quantity of the product under the seller's control normally equals or exceeds the quantity under the buyer's control. ${ }^{77}$ The seller, therefore, can gain knowledge of and correct possible defects more easily than the buyer.

To test whether the culpability scale operates with respect to article 2's warranty provisions, we would want evidence that, given the appropriate facts, the Code supplants risk allocation based on strict liability with allocation based on the intention, knowledge, or negligence principles. Because the seller bears the loss under strict liability (assuming that the

of "strict liability in tort."). See generally Prosser, The Assault Upon the Citadel (Strict Liability to the Consumer), 69 YALE L.J. 1099, 1124-34 (1960) (concept of warranty should be discarded in favor of strict liability).

75. U.C.C. \$2-312(1).

76. This judgment is reflected in $i d$. $\$ \$ 2-313$ to $2-316$.

77. As a product moves along the chain of distribution, the number of actors generally increases, so that each actor has a smaller number of products to test. Sampling for quality is more exact the greater the population from which the sample is extracted. See generally W. DIXON \& F. MASSEY, INTRODUCTION TO STATISTICAL ANALYSIS 58-61, 75-90, 95-106 (3d ed. 1969) (discussing requirements for adequate statistical samples). Where the buyer's size exceeds the seller's so that the legislative judgment based upon categories of persons is not applicable, the commercial parties of course may contract out of the Code's allocation of loss. See U.C.C. \$ 1-102(3); infra p. 289. And where, for other reasons, the buyer has superior ability to test the product at the time of purchase, the risk is allocated to him. See infra pp. 246-48. 
buyer has acted without intent, knowledge, or negligence), he would of course also bear the risk if he acted with intent, knowledge, or negligence. Thus, the search for the presence of the culpability scale must focus instead on the buyer, to see if a buyer who has acted with intent, knowledge, or negligence bears the loss rather than a seller innocent of such culpable conduct.

It may seem difficult to hypothesize situations in which a buyer intentionally creates a loss. One such example, however, might be the buyer who intentionally causes the defect after purchasing the product from the seller, and claims that the seller is responsible for it. ${ }^{78}$ In that situation, the Code's resolution would conform to the culpability scale. The buyer would have no redress and would therefore be left with the loss created by his own act. The ground for this resolution would be that the seller had not breached his warranty. ${ }^{79}$

78. One possible motivation might be the buyer's belated preference for a different product.

79. For breach of warranty purposes, the material issue is whether the product is nonconforming at the time of sale, not whether it later becomes nonconforming. Defects appearing after the time of purchase, however, may be held to constitute a breach of warranty, since they may reflect the product's inability to sustain the performance warranted. Thus, it could be argued that the defect was present at the time of purchase but only discovered later.

In addition to the situation discussed in the text, the buyer might violate the intention principle by purchasing a variety of products from one or more sellers in the hope that some will prove defective, thereby giving rise to one or more causes of action. According to his probability calculation, several products should be defective. The buyer might then sue the sellers of such defective products on breach of warranty grounds. Since the products have little utility other than as possible sources for litigation, the buyer might then sell off the remaining nondefective products for whatever value they bring. It is likely that the buyer would be denied recovery against the sellers of the defective products on any one of several theories. Most importantly, the buyer's conduct hardly conforms to the obligation, described in $\S 1-203$, "of good faith in [the] performance or enforcement" of every contract. The seller could raise the buyer's bad faith claim as a defense; the buyer would then be left with his loss. Cr. Neumiller Farms v. Cornett, 368 So. 2d 272 (Ala. 1979) (buyer's claim of dissatisfaction with goods made in bad faith, because of decline in market price); Peter Pan Seafoods, Inc. v. Olympic Foundry Co., 17 Wash. App. 761, 768-70, 565 P.2d 819, 824-25 (1977) (buyer held not to have acted in good faith where he delayed in notifying seller of defect even though buyer was aware of defect from time the product first used).

In any event, it is difficult to envision that the buyer could claim any damages cognizable by the Code. The Code's measure of damages for breach of warranty, excluding incidental and consequential damages, is "the difference at the time and place of acceptance between the value of the goods accepted and the value they would have had if they had been as warranted . . . U. U.C. $\$ 2-714(2)$. The hypothesized situation is one where the goods have a higher value to the buyer if they are defective than if they are not. The value of conforming goods to the buyer is limited to their salvage value. The value of the defective goods is probably at least equal to their salvage value.

Nor would the buyer be likely to recover incidental or consequential damages. The Code provisions relating to recovery for incidental and consequential damages are $\$ \S 2-714$ to $2-715$. Section $2-714$ 's use of terms and phrases such as "ordinary course of events," "any manner which is reasonable," and "proper care," connote a general requirement of reasonable conduct. Section 2-715 enunciates that requirement much more explicitly. Incidental damages are limited to "expenses reasonably incurred" in certain activities or "any other reasonable expense incident to the . . . breach." Consequential damages are limited to losses "which could not reasonably be prevented by cover or otherwise" or "injury to person or property proximately resulting from any breach of warranty." A buyer who has acted in violation of the intention principle has hardly conducted himself reasonably. Moreover, consequential damages are recoverable for "requirements and needs of which the seller at the time of contracting had reason to know . ..." Id. $\S 2-715(2)(a)$. A seller would hardly have reason to know 
It is also possible to hypothesize a situation in which the buyer, although not guilty of violating the intention principle, has acted with knowledge. Suppose, for example, that the buyer purchased goods with knowledge of their defects. The Code's language indicates that no warranty would have been given that could form the basis for suit. The Gode's warranty provisions generally allow the buyer to shift the loss to his seller when the buyer's reasonable expectations about the goods purchased have been frustrated. ${ }^{80}$ The short answer to the buyer's claim of breach of warranty when the buyer knew of the defect or nonconformity prior to the purchase is that his expectations have not been frustrated. Specifically, as to express warranties, any statements by the seller that the buyer knew to be false would not become "part of the basis of the bargain." As to implied warranties, the Code provides that "when the buyer before entering into the contract has examined the goods or the sample or model as fully as he desired or has refused to examine the goods there is no implied warranty with regard to defects which an examination ought in the circumstances to have revealed to him."'82 A fortiori, where proof exists that the buyer knew of the defect before the purchase, the statutory scheme precludes the creation of an implied warranty.

Suppose, however, that the buyer does not know of the defect prior to purchase but learns of it prior to use. One could argue that the buyer has violated the knowledge principle by using the goods with such knowledge if the asserted damages are incidental or consequential to that use. At least two Code provisions would prevent the buyer's recovery. First, a claim for damages that flowed from a defect. of which the buyer but not the seller was aware would be inconsistent with section 1-203's obligation of good faith performance and enforcement of contracts. ${ }^{83}$ Second, the use of goods

of the buyer's "need" for defective products.

80. This pattern of protecting reasonable expectations extends beyond the warranty provisions, of course. See id. § 2-609 \& comment 1 (right to adequate assurance of performance); see also Farnsworth, Legal Remedies for Breach of Contract, 70 COLUM. L. REV. 1145, 1147-49 (1970) (protection of reasonable expectations is controlling consideration in contract law generally).

81. U.C.C. § 2-313(1); see Fischback \& Moore Int'l Corp. v. Crane Barge R-14, 29 U.C.C. Rep. Serv. 1165, 1168 (4th Cir. 1980) (manufacturer of transformer damaged in transport because its weight was greater than that indicated on its side held not liable since the buyer "was aware of the weight discriminations and never relayed this information to any of the parties involved in shipping and loading the units").

82. U.C.C. $\S 2-316(3)(\mathrm{b})$.

83. See id. § 1-203. In addition, $\S 2-314$ comment 13 states in relevant part:

In an action based on breach of warranty, it is of course necessary to show . . . that the breach of warranty was the proximate cause of the loss sustained. In such an action an affirmative showing by the seller that the loss resulted from some action or event following his own delivery of the goods can operate as a defense. . . Action by the buyer following an examination of the goods which ought to have indicated the defect complained of can be shown as matter bearing on whether the breach itself was the cause of the injury.

The seller could also argue that the buyer's own choice, rather than the breach of warranty, caused the loss. 
known to be defective would not correspond with the reasonable conduct contemplated by section $2-715$, which defines those contexts in which incidental and consequential damages may be recovered. ${ }^{84}$

A more realistic scenario is one in which a buyer is assumed to have acted negligently. If the culpability scale were observed in its entirety, the risk of loss would fall upon the buyer. Common wisdom indicates, however, that the Code does not follow the culpability scale this far. The seller supposedly cannot assert the buyer's negligence as a defense in a suit based on breach of warranty. ${ }^{85}$ Yet this unqualified generalization overlooks the considerable role that the buyer's negligence can play. For example, section 2-316 holds the buyer to the equivalent of a negligence standard with respect to the creation of implied warranties at the time of purchase. ${ }^{86}$ The same section states that

unless the circumstances indicate otherwise, all implied warranties are excluded by expressions like "as is", "with all faults" or other language which in common understanding calls the buyer's attention to the exclusion of warranties and makes plain that there is no implied warranty. ${ }^{87}$

Phrases like "common understanding" and "ought in the circumstances" are objective in nature. This language, then, makes plain that implied warranties may be excluded based on the buyer's negligence at the time of

84. See supra note 79; see also Erdman v. Johnson Bros. Radio \& Television Co., 260 Md. 190, 271 A.2d 744 (1970) (buyer of television set that emitted sparks and smoke held to have acted unreasonably in continuing to use set and could not recover from seller for loss of house and other property damage); Michigan Sugar Co. v. Jebavy-Sorensen Orchard Co., 66 Mich. App. 642, 239 N.W.2d 693 (1976) (sugar buyer's act of reselling defective sugar despite knowledge that it would not pass customer inspection precluded recovery of lost profits from seller); Columbia Novelty Co. v. Leslie Dawn, Inc., 6 U.C.C. Rep. Serv. 679 (N.Y. App. Term 1969) (per curiam) (buyer, as "experienced" manufacturer, could not recover consequential damages since it "knew of the defects but used the goods and took a chance that its customers would not complain"). But see Prutch v. Ford Motor Co., 618 P.2d 657, 662 (Colo. 1980) (per curiam) (en banc) (farmers' knowledge of defective plow does not preclude recovery of consequential damages from manufacturer since manufacturer's "failure to provide [the plaintiffs] . . . properly functioning equipment left them a narrow range of alternatives," and plaintiffs' decision "to continue farming with the knowledge that their . . . equipment might continue to malfunction, actually mitigated their losses"); Burrus v. Itek Corp., 46 Ill. App. 3d 350, 358, 360 N.E.2d 1168, 1173 (1977) (printer could recover lost profits from seller of printing press, despite printer's continued use of press after he knew it to be defective, on ground that printer "had no choice in the matter in that the defendant [seller] refused to provide a replacement machine").

85. See Dagley v. Armstrong Rubber Co., 344 F.2d 245, 250 (7th Cir. 1965) (in action by truck driver against manufacturer, jury's verdict in favor of manufacturer on negligence count not res judicata as to warranty counts); Jacobs Pharmacy Co. v. Gipson, 116 Ga. App. 760, 762, 159 S.E.2d 171, 173-74 (1967) (court allowed action against seller of drug on warranty theory despite failure of plaintiff's mother to follow instructions on package, because "[i]n an action predicated on breach of warranty there is of course no defense per se of contributory negligence.").

86. U.C.C. $\S 2-316(3)(b) ;$ see supra p. 246 (quoting provision).

87. U.C.C. $\S 2-316(3)(a)$. 
purchase; therefore, the negligent buyer will bear any loss. ${ }^{88}$

What remains for discussion is the legal effect of the buyer's negligence after purchase of the product. ${ }^{80}$ Some courts have explicitly allowed sellers to base their defenses upon the buyer's negligence after purchase. ${ }^{90}$ Even when this defense is not allowed, the buyer's negligence may affect his rights in at least two ways. First, when the buyer has acted negligently, he will not be permitted to recover incidental or consequential damages. ${ }^{91}$ Second, negligent conduct might be asserted as the basis of an alternative defense such as assumption of risk. ${ }^{92}$ This defense, although not explicitly mentioned in the Code, could be claimed pursuant to section 1-103, which allows "principles of law and equity" to supplement the Code's provisions unless specifically displaced by particular provisions of the Code. ${ }^{93}$ With limited exceptions, then, even the warranty provisions of article 2, although they seem to be based exclusively upon strict liability, support the general presence and operation of the culpability scale.

\section{Risk of Mistaken Reliance upon the Debtor's Assets as Collateral}

Another risk generally considered to be allocated on the basis of the strict liability principle, without regard to intent, knowledge, or negligence, is the risk of mistaken reliance by multiple creditors on the same collateral. ${ }^{24}$ The reason for this common perception is that, in general, the priority of claims to collateral after default by the debtor is determined by the temporal order of filing or perfecting. ${ }^{95}$ The first secured party to ne-

88. See Refrigeration Discount Corp. v. Grouse, 2 U.C.C. Rep. Serv. 986 (Pa. Ct. C.P. 1965) (buyer who used tractor before purchasing it received no implied warranty).

89. After the purchase, the buyer may act negligently either in failing to discover the defect or in using the product.

90. See, e.g., Erdman v. Johnson Bros. Radio \& Television Co., 260 Md. 190, 271 A.2d 744 (1970) (buyer's negligent use of defective television barred his recovery against seller); Procter \& Gamble Mfg. Co. v. Langley, 422 S.W.2d 773 (Tex. Civ. App. 1967) (buyer's negligent use of permanent wave product barred her recovery against manufacturer).

91. See supra notes 79, 84; see also General Instrument Corp. v. Pennsylvania Pressed Metals, Inc., 366 F. Supp. 139 (M.D. Pa. 1973) (incidental and consequential damages denied to buyer where nonconformity was obvious and should have been discovered by the buyer), aff'd mem., 506 F.2d 1051 (3d Cir. 1974).

92. See Barefield v. La Salle Coca-Cola Bottling Co., 370 Mich. 1, 5, 120 N.W.2d 786, 788 (1963) (verdict for manufacturer sustained where buyer and consumer of soda bottle "should not have continued to drink its product after she discovered, or should have discovered, it contained glass particles"); cf. Williams v. Brown Mfg. Co., 45 Ill. 2d 418, 261 N.E.2d 305 (1970) (assumption of risk allowed as defense in action based on strict liability in tort); RESTATEMENT (SECOND) OF TORTS $\S$ $402 \mathrm{~A}$ comment 2 (1976) ("[T]he form of contributory negligence which consists in voluntarily and unreasonably proceeding to encounter a known danger, and commonly passes under the name of assumption of risk, is a defense under this section as in other cases of strict liability.").

93. U.C.C. § 1-103.

94. For expressions of this view, see J. WHITE \& R. SUMMERS, supra note $14, \S 25-4$, at 1037 ; Jackson \& Kronman, Secured Financing and Priorities Among Creditors, 88 YALE L.J. 1143, 116164 (1979).

95. See U.C.C. $\$ 9-312(5)$. Subsection (5) actually gives priority to the first creditor who either 
gotiate with the debtor has the opportunity to file notice of his security interest, if filing is the perfecting mechanism to be utilized. If he files first, he is appropriately rewarded with the priority to the collateral. If a second secured party files before him, the second party is rewarded. This result holds even if the second party knew of the first party's interest in the collateral. ${ }^{96}$ Reference in the article 9 comments to the "necessity of protecting the filing system ${ }^{\prime \prime 2}$ has reinforced the notion that this allocative scheme is distinctly neutral with respect to culpability.

The doctrinal history behind article 9's priority rules suggests a different view, however. At least since the passage of the Statute of Fraudulent Conveyances $^{88}$ in 1571 , the conveyance of an interest in property by a debtor has been viewed as fraudulent with respect to his other creditors and voidable by them if the property remained in his possession. The fraud consists of the false appearance that the debtor enjoys full property rights in the assets he possesses; there is a risk that third parties will rely on this appearance to their detriment. ${ }^{98}$ Karl Llewellyn, the Code's chief reporter and principal drafter, once observed that "[a]mong people after people ... we see secret offenses treated as peculiarly punishable . . ."100 or in other words, as the source of highest culpability. The law of fraudulent conveyances is a particularization of Llewellyn's more abstract observation. For the past several centuries, much commercial doctrine relating to creditor protection has revolved around whether a debtor's property transfer should be considered fraudulent as a matter of law, ${ }^{101}$ pre-

files or perfects his claim. The time of perfection is important only with security interests that are perfected by possession or other nonfiling acts. Some types of security interests, such as purchase money security interests, have special priority rules. See id. $\S 9-312(1)$ to (4).

96. In re Smith, 326 F. Supp. 1311 (D. Minn. 1971) (second secured party given priority even though had actual knowledge of first party's unperfected interest); see also Felsenfeld, Knowledge as a Factor in Determining Priorities Under the Uniform Commercial Code, 42 N.Y.U. L. REV. 246, 251 (1967) ("[T]he plain meaning of the statute is that a second secured party, even with full knowledge of a prior unperfected lien, may obtain priority over it by obtaining a lien and perfecting in accordance with Article 9."). It is significant that Grant Gilmore, the chief reporter for article 9, thought that priority should go to the first secured party. See 2 G. GILMORE, SECURITY INTERESTS IN PERSONAL PROPERTY $\S 34.2$ (1965). At least one court has granted priority, in the form of an equitable lien, to the first secured party when the second secured party, who filed first, had participated in the debtor's creation of the first security interest. The court held that the second secured party's conduct surpassed mere knowledge and amounted to bad faith. See General Ins. Co. of Am. v. Lowrys, 412 F. Supp. 12 (S.D. Ohio 1976), aff'd, 570 F.2d 120 (6th Cir. 1978).

97. U.C.C. \$ 9-312 comment 5, example 1.

98. Statute of Fraudulent Conveyences, 1571, 13 Eliz. ch. 5; see also Twyne's Case, 76 Eng. Rep. 809 (Star Chamber 1601) (conveyance ruled fraudulent when debtor retained possession). Much of fraudulent conveyance law today is codified in the Uniform Fraudulent Conveyance Act, which has thus far been adopted by 26 states. See 7A U.L.A. 27 (Supp. 1982).

99. See Phillips, Flawed Perfection: From Possession to Filing Under Article 9-Part I, 59 B.U. L. REV. 1, 2-8, 34-43 (1979).

100. Llewellyn, The Anthropology of Criminal Guilt, in K. LLEWELLYN, JURISPRUDENGE: REAL ISM IN THEORY AND PRACTICE 439, 440 (1962).

101. See Sturtevant \& Keep v. Ballard, 9 Johns. 337 (N.Y. Sup. Ct. 1812) (announcing principle of fraud-in-law). 
sumptively fraudulent (modified fraud-in-law), ${ }^{102}$ or fraudulent in fact. ${ }^{103}$ Within this historical context, the first-to-file rule reflects either the fraudin-law or modified fraud-in-law approach to fraudulent conveyance doctrine. Failure by the first secured party to file notice of his security interest can be interpreted as a per se category of conduct intended to cause others to rely to their detriment upon the debtor's assets. Thus, rather than simply perceiving the first secured party who does not file as that party who with least cost could have avoided the loss (this is undeniable), one can view his loss of priority to another secured party as an application of the intention principle.

If correct, this perspective explains why the second secured party takes priority in the collateral even if it knows of the first secured party's interest. The second secured party, while arguably having violated the knowledge principle, is still less culpable than the first secured party, who has violated the intention principle. This result clearly squares with the culpability scale.

But how can we know whether this analysis is correct? If, instead of reflecting the intention principle, the first-to-file rule reflects only the strict liability principle, then the priority accorded to a second secured party with knowledge of the first secured party's security interest would seem to contradict the culpability scale. The rule would operate as a repudiation rather than confirmation of the scale's existence.

Support for my analysis is found not only in the history of debtor-creditor law preceding the enactment of article 9, but also in an oft-neglected reference point, section 9-401(2). This provision states that a "filing which is made in good faith in an improper place or not in all of the places required by this section . . . is . . . effective with regard to collateral covered by the financing statement against any person who has knowledge of the contents of such financing statement."104 If the priority rules reflect solely the strict liability principle, the second secured party should still win in the situation that 9-401(2) addresses, provided only that the second secured party files properly prior to the first secured party. We would give priority to the second secured party for behaving in the ideal fashion first; the first secured party would have to pay the penalty for not behaving in the appropriate fashion. On the other hand, if the priority rules of article 9 reflect the culpability scale, we would expect the first secured party to win. The evidence of a filing made in good faith

102. See id. at 344 (conditional sale with explicit agreement that vendor retain possession for fixed term gives rise to rebuttable presumption of fraud); Davis v. Turner, $45 \mathrm{Va}$. (4 Gratt.) 422 (1848).

103. Proof of actual intent to defraud would be required in this case. See Uniform Fraudulent Conveyance Act $\S 7,7$ A U.L.A. 242 (1978).

104. U.C.C. § 9-401(2). 
would negate the inference that his failure to file properly occurred because of his intention to cause others to rely mistakenly upon the debtor's unencumbered ownership of assets. The first secured party, then, may have violated the negligence principle, but not the intention principle. And according to the culpability scale, a negligent party should have rights to the collateral superior to those of a party with knowledge.

\section{Foundations of the Culpability Scale}

The concept of a culpability scale has its roots in the moral tenet that it is selfish for one to engage in conduct that does not allow for the exercise of equivalent conduct by others. But the consideration that seems to have been principally responsible for the inclusion of the culpability scale in the Code is the instrumentalist notion that law can affect behavior. The scale's gradations reflect the relative probabilities that a designated commercial risk will materialize. Allocation of liability according to the scale imposes loss on the party who could have avoided it with least cost. The scale serves to reduce the risk of loss and thereby fosters efficiency and deterrence.

Process considerations also support the culpability scale. Given the difficulties of proof in our system of justice, certain facts regarding the state of an actor's intent or knowledge are unlikely to surface. The order of the four principles in the culpability scale is fashioned to take into account that difficulty of proof. $^{105}$

\section{A. The Moral Basis}

From time immemorial, various legal systems have assigned a greater degree of culpability to clearly voluntary conduct (conduct that, in the case of the Code, would violate either the intention or knowledge principles)

105. The pronouncements contained in much legal literature seem contrary to the synthesis of morality, economics, and process asserted in this Article. For example, the position that the culpability scale is based on both moral and economic considerations seems contrary to the argument, oft-repeated in current legal literature, that either moral or economic considerations, but not both, underlie rules that allocate loss. For the "moral" perspective, see Epstein, A Theory of Strict Liability, $2 \mathrm{~J}$. LEGAL STUD. 151 (1973); Epstein, Intentional Harms, 4 J. LEGAL STUD. 391 (1975). For the economic perspective, see R. POSNER, ECONOMIC ANALYSIS OF LAW (2d ed. 1977); Posner, Epstein's Tort Theory: A Critique, 8 J. LEGAL STUD. 457 (1979).

Similarly, the position that allocating loss according to the culpability scale is efficient stands in opposition to those scholars who find efficiency only in those rules that would allocate loss according to a causation-in-fact determination. Finally, this Article demonstrates that, with respect to commercial allocation of loss, process considerations reinforce rather than alter judgments that are reached using moral or economic criteria. For a somewhat contrary viewpoint, holding that, with respect to contract damages, process considerations require modification of the substantive rule that is most efficient if process concerns are excluded from consideration, see Goetz \& Scott, Principles of Relational Contracts, 67 VA. L. REV. 1089, 1146-49 (1981); Goetz \& Scott, Enforcing Promises: An Examination of the Basis of Contract, 89 YALE L.J. 1261, 1289-91 (1980). 
than to less voluntary conduct (conduct that, in the case of the Code, would violate either the negligence or strict liability principles). ${ }^{108}$ Today as well, most people would agree that the culpability scale reflects their own assessment of the relative moral blameworthiness of different conduct, and further, would place responsibility for loss on the party with greater culpability. The question is why this should be the case.

Unlimited pursuit of one's self-interest will eventually preclude others from pursuing their self-interest on a relatively equal basis. Morality is frequently defined in terms of restraining the pursuit of self-interest in favor of promoting a reciprocal recognition of rights and interests among all. ${ }^{107}$ Selflessness, respect for others, and cooperativeness, for example,

\section{Aristotle stated:}

Now when (1) the injury takes place contrary to reasonable expectation, it is a misadventure. When (2) it is not contrary to reasonable expectation, but does not imply vice, it is a mistake (for a man makes a mistake when the fault originates in him, but is the victim of accident when the origin lies outside him). When (3) he acts with knowledge but not after deliberation, it is an act of injustice-e.g. the acts due to anger or to other passions necessary or natural to man; for when men do such harmful and mistaken acts they act unjustly, and the acts are acts of injustice, but this does not imply that the doers are unjust or wicked; for the injury is not due to vice. But when (4) a man acts from choice, he is an unjust man and a vicious man. Aristotle, Ethica Nichomachea, in INTRODUCTION TO ARISTOTLE 300, 415 (R. McKeon ed. 1947). If negligence, strict liability, knowledge, and intention are substituted for "misadventure," "mistake," "act of injustice," and "unjust," it is apparent that Aristotle's culpability scale tracks the Code's scale almost exactly. Maimonides also articulated a culpability scale when he synthesized the Jewish law of torts approximately 800 years ago. See THE CODE OF MAIMONIDES: THE BOOK OF TORTS 179-212 (H. Klein trans. 1954).

In modern times, those scholars who best recognized the relationship between culpability and morality were Jerome Michael and Herbert Wechsler, whose primary focus was the criminal law of homicide, see Michael \& Wechsler, A Rationale for the Law of Homicide (pts. 1 \& 2), 37 CoLUM. L. REV. 701, 1261 (1937), and Lon Fuller, whose perspective was broader:

The whole body of the law was permeated by two recurring standards of decision: fault and intent. Philosophic discussion of these notions has largely concentrated on their role in the criminal law, where they have given rise to the most abstruse arguments, including that concerning freedom of will. But these twin standards play an equally important role in the law of contracts, torts, and property. Examined closely they turn out to be difficult and elusive conceptions in whatever area of the law they appear. Yet without them we would have no thread to guide us through the labyrinth. When one of them fails, we are apt to reach for the closest approximation of it. When there is no clearly determined intent, we ask what intention the parties would have had had they foreseen the situation that has arisen. When neither party seems chargeable directly with fault, we ask which of them had the best chance to prevent the harm-which, in other words, was closest to being at fault.

L. FULLER, THE MORALITY OF LAW 167 (rev. ed. 1969). Fuller related this nexus in the substantive law to a view of man as a responsible agent, the same perspective that underlay his conception that law should correspond to "internal" as well as external moral standards.

107. Illustrations include the biblical injunction to "love thy neighbor as thyself." Leviticus 19:18. This verse synthesizes the five commandments in the decalogue which speak of man's duties towards other people. In fact, when a gentile once commanded Hillel to teach him the whole law while standing on one foot, Hillel remarked, "What is hateful to you do not to your neighbor; that is the whole Torah, while the rest is the commentary thereof." See BABYLONIAN TALMUD, Shabbath 31a (H. Freedman trans. 1938). Perhaps most definitive is Immanuel Kant's first formulation of the catcgorical imperative: "Act only on that maxim through which you can at the same time will that it should be a universal law!" I. KANT, GROUNDWORK OF THE METAPHYSIC OF MORAIS 88 (H. Paton trans. 1964).

Nor would David Hume or John Stuart Mill disagree. Hume and Mill, in particular, defined 
are generally considered to be morally superior to selfishness, disrespect for others, and uncooperativeness. ${ }^{108}$ The culpability scale reflects this same ordering; as transgressions move up the scale, the implicit disrespect they embody increases.

At the top of the scale, the actor intends harm to the party or parties affected by his conduct. Such intent may not rise to the level of sadism (as might a particular intentional murder), but the commercial actor will have chosen to cause harm for his own gain. This choice to cause harm to another can be characterized as selfish, disrespectful, and uncooperative. ${ }^{108}$ Indeed, the person who will be harmed is, in the mind of the actor, simply an object to be used in the absolute and unrestrained pursuit of the actor's self-interest. ${ }^{110}$

utility in terms of the greatest happiness of all, not simply in terms of the actor's advantage. See D. HUME, AN ENQUIRY CONCERNING THE HUMAN UNDERSTANDING AND AN ENQUIRY CONCERNING THE PRINCIPLE OF MORALS 183 (L. Selby-Bigge ed. 1894) ("[P]ublic utility is the sole origin of justice, and . . . reflections on the beneficial consequences of this virtue are the sole foundation of its merit."); J. MILL, UTILITARIANISM 15-16 (D. Piest ed. 1957) ("IT]he utilitarian standard . . . is not the agent's own greatest happiness, but the greatest amount of happiness altogether."). To Mill, "[some]thing . . . which people forbear to do from moral considerations . . . is of a class which, if practiced generally, would be generally injurious, and ... this is the ground of the obligation to abstain from it." Id. at 25.

Lon Fuller aptly summed up the history of Western moral philosophy as follows:

What the Golden Rule seeks to convey is not that society is composed of a network of explicit bargains, but that it is held together by a pervasive bond of reciprocity. Traces of this conception are to be found in every morality of duty, from those heavily tinctured by an appeal to self-interest to those that rest on the lofty demands of the Categorical Imperative. Whenever an appeal to duty seeks to justify itself, it does so always in terms of something like the principle of reciprocity.

L. FULLER, supra note 106, at 20.

I do not mean to assert that each of these diverse authorities would necessarily agree with every succeeding statement in the text. Nor would they agree upon the source of their definitions of morality. Thus, the biblical injunction to love one's neighbors is ascribed by some to divine revelation; to Kant, the source is a priori reasoning, and to Mill, the utilitarian standard of the greatest happiness of all.

108. See, e.g., D. HUME, supra note 107, at 181 ("[N]othing can bestow more merit on any human creature than the sentiment of benevolence in an eminent degree."); J. MILL, supra note 107, at 21 ("Though it is only in a very imperfect state of the world's arrangements that anyone can best serve the happiness of others by the absolute sacrifice of his own, yet, so long as the world is in that imperfect state, I fully acknowledge that the readiness to make such a sacrifice is the highest virtue which can be found in man.").

109. For a forceful articulation of the centrality of choice-and specifically, a discussion of whether one's choice is manifested in respect for others-in a system of morality, see C. FRIED, RIGHT AND WRONG (1978).

110. One could add that because an actor considers the other person an object to be used, the actor's conduct violative of the intention principle reflects his real commitment to a slavish rather than free society, provided only that he enjoys the upper hand.

Kant expressed the immorality of treating others as objects in the following manner: "Rational beings .... are called persons because their nature already marks them out as ends in themselves-that is, as something which ought not to be used merely as a means-and consequently imposes to that extent a limit on all arbitrary treatment of them. . . ." I. KANT, supra note 107, at 96. Consequently, his articulation of the categorical imperative as a practical imperative was: "Act in such a way that you always treat humanity, whether in your own person or in the person of any other, never simply as a means, but always at the same time as an end." Id. (emphasis omitted). This 
The actor who violates the knowledge principle will not have intended to cause harm to another party in precisely the same manner. He will have acted knowingly in seeking to avoid loss to himself by shifting it to another party, but he is not the party who created the risk. From an economic perspective, seeking gain and avoiding loss might be equivalents, but from a moral perspective the two differ. The party who knowingly transfers a forged negotiable instrument may prefer that neither he nor the transferee suffer loss, but rather than bearing the loss himself, he still treats the transferee as an object. He is culpable to a lesser degree than the party who forged the instrument and thus intentionally chose that someone suffer a loss, ${ }^{111}$ but his actions still are characterized by selfishness, disrespect, and uncooperativeness.

Negligence, too, involves choice, although to a lesser degree than intentional or knowing conduct. Pursuit of self-interest has blinded the negligent actor to the same considerations that others acting reasonably would have entertained. In ignoring these considerations, the negligent actor has subjected others to risk, thereby showing disrespect for them. His conduct further shows a lack of cooperativeness. The degree of freedom that the negligent actor allows himself is such that, if enjoyed by others, would prevent society from functioning efficiently.

Finally, the party who violates the strict liability principle can also be said to have exercised a choice. When a commercial loss has not been avoided, the least costly loss avoider has acted more selfishly than other involved actors, because prevention of the loss would have required expenditure of fewer resources by him than by the others. In such a situation, the extent of the actor's commitment to a society where people enjoy equivalent rights is questionable. ${ }^{112}$

imperative has been referred to as "the fundamental principle of common morality." A. DONAGAN, THE THEORY OF MORALITY 229 (1977).

111. It might be asserted that someone whose savings are robbed and who then secks to recoup by forging a check is less immoral than a millionaire who passes on a forged check in order to avoid a $\$ 10$ loss. Whatever the merit of this perspective, legal doctrine-even if morally based-must be based on models of actors. The only claim I make here is that, all other things being equal, the intentional actor is more culpable than the knowing actor.

112. By failing to spend the resources necessary to avoid loss, the actor implicitly adheres to the selfish attitude that, even though his expenditures would have been less, the other party should have expended greater resources if loss was to be prevented. I therefore believe that Professor Ames was mistaken when he assumed that, while a negligence standard is ethically grounded, one based upon strict liability is not so grounded. See Ames, Law and Morals, 22 HARV. L. REV. 97 (1908). George Fletcher and John Silber, in contrast, avoided that error. Fletcher recognized that situations in which strict liability is imposed involve the creation of nonreciprocal risks by the defendant to the plaintiff. See Fletcher, Fairness and Utility in Tort Theory, 85 HARV. L. REV. 537, 544-48 (1972). Silber, relying largely upon psychology, characterized voluntary conduct and involuntary conduct (or status) as lying along a continuum of moral responsibility. See Silber, Being and Doing: A Study of Status Responsibility and Voluntary Responsibility, 35 U. CHI. L. REV. 47, 90 (1967). 


\section{Commercial Culpability Scale}

\section{B. The Instrumentalist Basis}

Not only does the culpability scale produce what we believe to be a morally just result, but it also serves the instrumentalist goal of minimizing the level of risk. ${ }^{113}$ While this instrumentalist basis may seem less intuitive than the moral basis just discussed, the insight it provides into the operation of the Code may be the most important contribution that the culpability scale makes.

Specifically, an instrumentalist analysis includes, first, an identification of specific commercial risks and, second, the allocation of loss to that party who increased the risk more than his commercial adversary. The party whose conduct incurred the higher probability of loss, it will be shown, is also the party who with least cost could have avoided the occurrence of the loss.

The Code's drafters quite explicitly took the first step of an instrumentalist approach by organizing the Code's provisions around identifiable risks. ${ }^{114}$ The other element of instrumental or risk analysis is implicit in the Code's allocation of loss according to the culpability scale. The ordering of the culpability scale's principles reflects the degree of risk that the conduct falling within that principle generates. Consequently, once commercial loss occurs, the culpability scale allocates it to the party whose conduct incurred the greatest risk of loss-the same party who could have avoided loss with least cost. Allocation of loss in this fashion best deters commercial actors from engaging in loss-creating conduct in the first place. The remainder of this section elaborates upon the nexi described above: the relationships between the culpability scale and the probability of loss from the conduct of commercial parties, and between the scale and the instrumentalist goal of risk reduction.

Consider, first, the level of risk that one's conduct creates. Normally, it is more likely that an actor will cause a result that he is actively seeking to bring about than that he will cause a result he has either no desire to bring about or is unaware of. ${ }^{116}$ The ordering of the culpability scale reflects this intuition that intentional conduct is more likely to cause a particular loss than is less culpable conduct. If an intentional actor is compe-

113. This is not to deny that any case in which two parties are contesting liability over a past event must, by definition, involve a retrospective distribution of wealth. But the key issue is whether, in resolving the equities between these parties, the rule of liability will best tend to deter other commercial parties who are similarly situated from incurring loss.

114. See, e.g., U.C.C. $\$ \S 3-401$ to 3-406 (forgery), 2-312 to 2-318 (breach of warranty), 2-401 to 2-403 (theft of goods), 7-501 to 7-504 (theft of documents of title covering goods), 9-301 to 9-316 (reliance by multiple creditors on the same collateral).

115. The clearest exposition of this is found in Michael \& Wechsler, supra note 106, at 723-24, 1274-84. For a more recent recognition of this relationship, see Rizzo \& Arnold, Causal Apportionment in the Law of Torts: An Economic Theory, 80 CoLUM. L. REV. 1399, 1423 (1980). 
tent, the risk of loss approaches certainty; for example, once a forger successfully deludes at least one person, someone will bear a loss, even if the forger is apprehended. ${ }^{116}$

If our concern is the possible imposition of loss upon a subsequent party, then the risk accompanying knowledgeable conduct is almost identical to the risk associated with intentional conduct. If we use the example of the forged instrument, the only difference between the two situations is that the party with intent actually forged the check; the party with knowledge merely received it from another party. Once in possession of the forgery, however, parties with knowledge and intent act very similarly.

The actor who violates the negligence principle is less likely to cause loss than the intending or knowing actor. With respect to certain risks-for example, forgery or theft of goods-negligence alone will not produce loss. The negligence increases the risk of loss from forgery or theft, however, because it facilitates conduct by another who would violate the intention or knowledge principles. In other cases, where intentional or knowing conduct on the part of another is not in issue, negligent conduct can itself cause the loss. The manufacturer who carelessly produces goods or the bailee who fails to exercise reasonable care in storing bailed goods has, by definition, raised the risks that inhere in purchase of goods or storage transactions above the normal levels.

One whose failure to act would violate the strict liability principle similarly can be perceived as increasing the risk more than his adversary, if the latter has not violated the intention, knowledge, or negligence principles. Since he is in a position to have avoided the loss at less cost than his adversary, his failure to expend the resources to avoid loss increased the risk more than his adversary's failure to act. ${ }^{117}$

Consider next an alternative frame of reference: efficiency. Not only does the culpability scale order liability according to the probability that the commercial parties' conduct will result in loss, but the scale also allo-

116. Even in that case commerce has been interrupted, transaction costs, including possibly legal costs, must be incurred to insure that the forger bears the loss, and the forger may have become insolvent or hidden his assets.

117. It should be understood that the actor's violation of the strict liability principle is not necessarily unreasonable. The payor bank that fails to check the drawer's signature on numerous small checks that do not show any noticeable signs of forgery may be acting quite reasonably, for example. Because the payor bank has a copy of the drawer's signature, however, its ability to check authenticity of the signature on checks exceeds the ability of a holder of the instrument who lacks a copy of the signature. By definition, the payor bank's failure to expend certain resources to police the forgery risk has increased the probability of forgery more than an equivalent failure by a holder to expend the same amount of resources. Cf. Signature Verification-The Calculus of Risk, 99 BANKING L.J. 263 (1982) (payor banks do not always verify drawers' signatures on checks for small amounts).

It may be thought this could be true even if the holder were negligent. The negligence of the holder, however, will usually consist of his failure to pay attention to facts known to him. Violation of the negligence principle rarely occurs in the context of a failure to expend additional resources to determine information. 
cates loss to the party that could avoid it with least cost. Where the parties recognize the potential for loss and can explicitly allocate the risk by contract, they will, through bargaining, place the risk on the party who can bear it with least cost. ${ }^{118}$ Not all risks can be allocated efficiently by contract, however. ${ }^{119}$ Imposition of liability based on the culpability scale allocates loss efficiently in those situations where the parties cannot do so explicitly or should not be required to do so because their allocation would be obvious. While cost minimization is an evident objective of the strict liability principle, it is also achieved by applying the culpability scale's other principles. ${ }^{120}$

118. This allocation would occur because the difference between the cost of loss avoidance to that party and the greater cost that would otherwise have to be expended by the other party could then be shared to the benefit of both parties.

119. Although some commercial adversaries have earlier been in contractual privity, others have not. And, although some of those who have dealt with each other have explicitly identified and contractually allocated the particular commercial risk, others have not. Moreover, if the hypothesized allocation of risks between parties is so obvious, requiring the parties to state the allocation explicitly is a needless and therefore inefficient expenditure in itself. See Demsetz, When Does the Rule of Liability Matter?, 1 J. LEgal STUD. 13, 27-28 (1972); Kronman, Mistake, Disclosure, Information and the Law of Contracts, 7 J. LEGAL STUD. 1, 4 (1978).

120. In addition to the textual analysis that follow, another method of establishing the culpability scale's efficiency is to compare the results it achieves to an allocation that would accord with the putative expectations of the parties. Presumably, as the best approximation of what the parties would have decided had they explicitly allocated the risk, this solution is efficient. See R. POSNER, supra note 105, at 10-11; Priest, Breach and Remedy for the Tender of Nonconforming Goods Under the Uniform Commercial Code: An Economic Approach, 91 HARV. L. REV. 960, 961-62 (1978).

It is easy to show that allocating loss by culpability will produce the same results as allocating it by reasonable expectations. The more a party's conduct is blameworthy according to the culpability scale, the greater is the variance between that party's conduct and what his adversary reasonably expected prior to transacting. If the innocent party knew that the other side intended to defraud him or had acted carelessly, for example, his conduct would probably change substantially. He might not engage in the transaction at all; he might require greater compensation in light of the much greater probability of loss or costs; or he might, in conjunction with requiring greater compensation of transacting, take additional preventive measures against the risk. Because the party who violates a principle of the culpability scale deals in the same commercial environment, he should be aware of the other party's reasonable expectations and therefore calculations of risk. Cf. U.C.C. $\$ \S 1-205(2)$ ("A usage of trade is any practice or method of dealing having such regularity of observance in a place, vocation or trade as to justify an expectation that it will be observed with respect to the transaction in question."), 1-205(5) ("An applicable usage of trade in the place where any part of performance is to occur shall be used in interpreting the agreement as to that part of the performance.").

Suppose, for example, that a manufacturer of goods discovers that certain of its goods are defective. Not wanting to be stuck with a loss on these goods (and in violation of the knowledge principle), it sells the goods to a retailer. The retailer does not discover the defect despite the opportunity to do so (thereby violating the negligence principle). Had the retailer known that the manufacturer was knowingly selling defective goods, the retailer would have assessed the risk of defective goods differently and exercised more care than it did. Presumably, exercise of such care would have resulted in a decision either not to purchase the goods or to pay less for them. The manufacturer's knowing conduct frustrated the reasonable expectations of the retailer. In contrast, it can hardly be said that the retailer's negligence frustrated the expectations of the manufacturer.

It may be argued that law and expectations are circular-that law both influences and is influenced by expectations. Consequently, it would make no sense to justify any particular state of law on the basis of present expectations and behavioral patterns resulting from these expectations. More specifically, if commercial law left losses where they fell rather than redistributing them, commercial parties would simply adjust their risk assessment in light of an experience that includes intentional, knowing, negligent, and comparatively inefficient conduct on the part of commercial actors. 
At the top of the culpability scale is that party who violates the intention principle. He can spend fewer resources than any other party to prevent each loss; assuming that he is mentally capable of controlling his own acts, no action beyond changing his mind is necessary on his part to prevent the risk. ${ }^{121}$ For example, if there is to be fraud in a sales transaction or forgery of an instrument, he knows the specific sources of the fraud or forgery, the manner by which it will be effected, and the number of possible cases.

The prevention costs of the actor who would violate the knowledge principle must be viewed from two perspectives. It should be recalled that the party who would violate the knowledge principle is that unlucky person who finds himself in a loss situation, either of his own creation or another's, and seeks to transfer the loss to another party. If prevention is viewed from the perspective of limiting the spread of loss to subsequent parties, the actor with knowledge is in the same position as the actor with intent. He knows what his situation is, what he wants to do, and what must be done to prevent his passing the loss to another.

There is another consideration, however, if the party with knowledge is not the party who created the loss. To prevent the loss from falling on himself, the party with knowledge must incur the cost of locating the loss creator and seeking restitution. The party with knowledge incurs a higher cost in this situation than in those in which one need alter only one's own behavior. Still, he is closer to the loss-creating situation and therefore can seek restitution more easily than could some subsequent party.

To the party who would violate the negligence principle, the cost of avoiding loss exceeds the costs to those actors who would violate either the

The argument that law and expectations are so intertwined that the former cannot be justified on the basis of the latter, however, rests upon certain assumptions that are questionable in the real world, most notably that people know of and react almost instantaneously to all information relevant to their positions. In the law and development area, it has long been recognized that behavior does not necessarily and immediately change simply because of the enactment of a law designed to foster different conduct. See Dror, Law and Social Change, 33 TULANE L. REV. 787, 794-801 (1959). While the correspondence between law and commercial practice may be greater in a developed country, numerous examples of "lag" may be cited. For example, long after such cases as In re Dolly Madison Indus., Inc., 351 F. Supp. 1038 (E.D. Pa. 1972), aff'd, 480 F.2d 917 (3d Cir. 1973), substantially left in doubt the utility of escrow arrangements as security devices, lawyers continued to use escrows on the assumption that the property in escrow is not subject to the claims of the debtor's creditors.

121. His only "cost" in preventing loss seems to be the opportunity cost of foregoing the situation creating the windfall. Yet abstinence on this score is precisely the bargain that people have struck with each other through society's rules. The law not only does not recognize this opportunity cost, but one of its specific aims is to deter it. See supra pp. 252-55.

It may be that this insight shows that values other than efficiency are ultimately at stake. Debate about this question rages in the literature. See, e.g., A Response to the Efficiency Symposium, 8 HOFSTRA L. REV. 811 (1980); Symposium on Efficiency as a Legal Concern, 8 HofsTRA L. REV. 485 (1980); Englard, Book Review, 95 HARV. L. REV. 1162 (1982) (reviewing R. POSNER, THE ECONOMICS OF JUSTICE (1981)). This issue is not raised here, however, because notions of morality and efficiency reinforce each other with respect to the culpability scale. 
intention or knowledge principles. First, his information costs are greater ${ }^{122}$ because he is not aware that he is creating a loss or passing on a loss created by others. Second, he must alter his behavior so that it conforms to reasonable standards of care. By doing so, he incurs the cost of restructuring the activity in which he was involved; in addition, he must incur the opportunity cost of foregoing his original activity. If he did not create the situation giving rise to loss, he also incurs the cost of finding the party who did, and seeking restitution.

Finally, the party who violates the strict liability principle incurs the greatest costs in avoiding loss. First, the monitoring costs of this party are the greatest. ${ }^{128}$ Modifying this party's behavior to avoid liability is also more costly. To avoid being negligent, one need only act reasonably, which in most instances simply means to cease conduct that differentiates the actor from most others like him. The steps required to avoid violation of the strict liability principle are usually greater. In fact, they may be so large in relation to the probability of loss that the commercial party who would be held responsible for loss pursuant to the strict liability principle (in the absence of his commercial adversary's violation of the intention, knowledge, or negligence principles) may decide not to take any preventive measure. ${ }^{124}$

To illustrate the comparative positions of the negligent party and the strictly liable party, suppose the drawer's signature has been forged on an instrument. Suppose, further, that a depository bank that negligently failed to discover the forgery when it acquired the instrument and the

122. In this regard, it may be inquired whether efficiency or morality would be served by treating as more culpable the knowing party who knows only because he made the reasonable inquiries that the negligent person should have made. Anthony Kronman goes so far as to argue that "allocational efficiency" is fostered by rewarding the contracting party who deliberately procures and then uses information unknown to his counterpart. Kronman, supra note 119, at 17. But Kronman's argument is difficult to accept with respect to most of the commercial risks that the Code specifically addresses. Significantly, many of his examples relate to real property; such property will not be put to its "best" (that is, highest valued) use unless information is first gathered at great expense. It is difficult to see what function is served by inducing the procurement of information, if the sole result of acquiring that information is the ability to transfer a defective instrument or product to another without liability.

123. Compare the information costs of the party who would violate the strict liability principle with those incurred by the negligent party. The latter's negligence frequently consists of the failure to respond reasonably to known facts. He is not required to act affirmatively to discover unknown facts and circumstances. See U.C.C. \$1-201(25) ("A person has notice of a fact when . . . (c) from all the facts and circumstances known to him at the time in question he has reason to know that it exists."). In contrast, the party who would violate the strict liability principle (without also violating the negligence principle) lacks reason to know of the degree of risk in the particular transaction, even though he is aware of the risk generally. He must expend some resources to discover the same facts known to the negligent party.

124. This has been characterized as an efficient breach. See R. POSNER, supra note 105, at 88-90; Goetz \& Scott, Liquidated Damages, Penalties and the Just Compensation Principle: Some Notes on an Enforcement Model and a Theory of Efficient Breach, 77 CoLUM. L. REV. 554, 558-77 (1977). Although it may be possible to have efficient breaches of a negligence standard, presumably they occur much more rarely by virtue of the assumption that such conduct is unreasonable. 
payor bank who paid the instrument despite the forged signature are now contesting who should bear the loss. The information costs faced by the negligent party were low since the asserted negligence consisted of its failure to pay reasonable attention to information already known to it. The information costs faced by the payor bank included structuring a system to discover forgery of the drawer's signature, not knowing when and whose particular signature might be forged. In fact, that cost is often so high that many banks, in their role of payors or drawees, do not undertake to discover forgeries except on instruments of large amounts, preferring to bear any intermittent losses from forgeries of drawers' signatures. ${ }^{125}$

For our purposes, the most important corollary that follows from the nexi between culpability and risk, and culpability and efficiency, is that loss allocation based on culpability will minimize commercial losses. The economic explanation for the deterrent effect of the culpability scale is relatively clear: An actor will incur the costs necessary to avoid the risk of a future loss if the costs are less than the present value of that loss, taking into account the probability that the loss would occur. The cheaper an actor's avoidance costs are, the likelier it is that the present value of the loss will exceed those costs and, therefore, that he will act to minimize losses. Because the cost of avoiding the loss decreases as one ascends the culpability scale, one who otherwise might be tempted to act with greater culpability is more likely than another to avoid loss-that is, to decide not to be culpable-if loss is imposed on him. Placing the risk of loss on the less culpable party, who would have to expend more resources to avoid it, will have comparatively less deterrent effect. ${ }^{126}$ The analysis in terms of risk is similar: Because the risk engendered by one's conduct increases as one ascends the culpability scale, placing the loss on the less culpable of the commercial actors would decrease the level of risk less than imposing liability on the more culpable party. In sum, in order to minimize losses, the behavior we most want to modify is that of the more culpable party. ${ }^{127}$

Although the culpability scale most notably serves to minimize losses, deterrence is not achieved at the expense of compensatory goals. Imposition of liability is itself, of course, compensatory. Moreover, levels of awareness of the probability of loss can be expressed as degrees of fore-

125. See supra note 117 .

126. This argument assumes that all other things are equal for the two contestants, for example, that they have the same marginal utility for money.

127. On an intuitive level as well, it makes sense to conclude that the allocation of loss according to the culpability scale achieves greater deterence than would allocation of loss contrary to the scale. An actor is better able to control and therefore alter his conduct the more he is aware of it. The culpability scale, beginning with the intention principle, represents a greater to a lesser state of awareness on the actor's part. Liability imposed according to the culpability scale therefore rests liability on those actors who are most able to control and alter their conduct. 
sight of the risk. A party who possesses foresight of risk is more likely to procure insurance that accomplishes the compensatory goal of spreading the risk. ${ }^{128}$ Even the actor who violates the knowledge principle would be eligible for insurance, in that his culpability usually relates not to the initiation of the transaction by which he obtained the goods, instrument, or document, but to his later conduct in seeking to shift the loss to another. Only the actor with intention would seem ineligible for, and undeserving of, insurance.

\section{The Process Basis}

Process considerations, especially difficulties of proof, help to explain why the culpability scale includes at least four principles of culpability. To some, the presence of the negligence principle may be particularly problematic. ${ }^{129}$ The scale's division into four levels of culpability, including the negligence principle, rather than three, without that principle, better enables the legal process to assign responsibility to an actor according to his true level of culpability.

To see why this is so, we must first appreciate the relative difficulty of proving the various levels of culpability. Intention is more difficult to prove $^{130}$ than knowledge, knowledge more difficult to prove ${ }^{131}$ than negligence, and negligence more difficult to prove $\mathrm{e}^{\mathbf{3 2}}$ than the status of the parties, ${ }^{133}$ when status serves as the basis for characterizing conduct as viola-

128. See Calabresi, Concerning Cause and the Law of Torts: An Essay for Harry Kalven, Jr., 43 U. CHI. L. REv. 69, 75 (1975).

129. See Epstein, Defenses and Subsequent Pleas in a System of Strict Liability, 3 J. LEGAL STUD. 165, 181 (1974) (arguing, in the context of tort law, that liability based on strict liability is fairer than liability based on negligence); infra pp. 269-77.

130. Intention is the most difficult to prove. Absent an admission by the actor, there is no way to prove with certainty that an actor intended to cause harm, even if he is seen committing the act that gave rise to loss. Instead of requiring such proof, the gap between factual observation and a rule of law requiring proof of intention often is bridged by a presumption that an actor subjectively intends the natural and foreseeable consequences of his objective conduct. See Calabresi, supra note 128, at 80.

131. Testimony that the fact was brought to the attention of the actor will usually suffice as proof of knowledge. See First Nat'l Bank v. Fazzari, 10 N.Y.2d. 394, 179 N.E.2d 493, 223 N.Y.S.2d 483 (1961); see also U.C.C. $\S \S 1-201(25)$ ("A person has notice of a fact when . . . (b) he has received a notice or notification of it . . .."), 1-201(26) ("A person 'receives' a notice or notification when (a) it comes to his attention. . .."). The necessary presumption is that the actor still retains this knowledge at the time of the specific act.

132. Here, proof that the actor knew of the loss-creating situation (for example, the forgery of the check) is unnecessary. Rather, proof relates to facts and circumstances of which the actor was aware and which gave him reason to know of the loss creating situation. See id. $\S 1-201(25)(c)$.

133. Placement of an actor into the least costly loss avoider category, when the categories have been predetermined by legislative judgment, is easiest of all. For example, in the case of forgery, the parties, by admitting the order in which they transferred the instrument, will settle the question of status. See id. $\S \S 3-417(1)$ (a) ("any prior transferor" warrants), 3-417(2)(a) (warranties run to "transferee" and "if the transfer is by indorsement to any subsequent holder"), 4-207(2)(a) (warranties run to "transferee" and "any subsequent collecting bank") (emphasis added). 
tive of the strict liability principle.

Because the levels of culpability vary in difficulty of proof, it is probable that some actors truly guilty of a higher level of culpability may be proved guilty of only a lower level. ${ }^{184}$ For example, a commercial party may have knowingly transferred a forged instrument, but proof may be limited to facts and circumstances that gave that party reason to know of the forgery. If the rule of law allocating loss did not incorporate the negligence principle, then it is quite likely that two levels of culpability would be skipped, rather than just one. In a contest between an actor who violated the knowledge principle and another who violated the strict liability principle, the loss might be borne by the latter. Therefore, the instrumentalist consideration of risk reduction would be doubly undermined by a rule of law that omitted one or more of the culpability scale's constituent principles.

Furthermore, because the culpability scale reflects deeply rooted feelings about the relative blameworthiness of different parties' conduct, ${ }^{135}$ judicial hostility to rules allocating loss contrary to the scale could be anticipated. Courts might react by judicially creating a level of culpability corresponding to the principle that was omitted, despite statutory language to the contrary. ${ }^{138}$ There is some evidence that this currently occurs

134. This may occur despite the presumptions used. See supra notes 130, 131.

135. See supra p. 262.

136. This judicial tendency is observable in several different places. Courts have tended to convert the contributory negligence provisions of $\$ \S 3-406$ and 4-406 into comparative negligence provisions, thereby pinning the loss on the more negligent party. See supra note 62 .

Courts have also reacted to apparent omissions of one of the culpability scale's four constituent principles. For example, the Code apparently omits the negligence principle in allocating loss when a depository collecting bank sues the party whose negligence contributed to the forgery of the latter's name as drawer of an instrument. Such a suit would arise if the payor bank, having paid the forged check, chose to recredit the drawer's account and collect from the depository collecting bank for breach of warranty of presentment. See $\$ \S 3-417(1)(b), 4-207(1)(b)$. Because $\$ 3-406$ is drafted using the terminology of estoppel (the negligent party "is precluded from asserting . . . the lack of authority") and the depository collecting bank's suit could not be based on the drawer's contract to pay under § 3413(2) (since the check has not been dishonored), the Code would seem to allow the loss to fall on a party who violated the strict liability principle rather than on one who violated the negligence principle. These facts arose in Girard Bank v. Mount Holly State Bank, 26 U.C.C. Rep. Serv. 1210 (D.N.J. 1979). In that case, the court fashioned a remedy based upon a negligence standard found outside of the Code, on the basis of $\$ 1-103$. In doing so, the court quite clearly saw the pattern of liability that the Code's drafters sought to establish:

Here a cause of action would further the Code policy favoring deterrence of the actor best able to prevent the fraud. Courts should be hesitant to improvise new remedies outside the already intricate scheme of Articles 3 and 4. However, this new cause of action would not interfere with that scheme but extend its principles to a situation not specifically foreseen by the drafters.

-..

Here, too, a negligence action could allow the loss to be shifted to a party which was in the best position to have prevented the forgery. Such a policy is implicit in $\$ \S 3-405,3-406$ and 4406. While this situation is not encompassed by $\S 3-405$ and subsections (1) and (4) of $\S 4-$ 406 , it is within the ambit of $\S 3-406$. However, because of the rigid limitation written into $\S$ 4-406(5) the policy behind $\S 3-406$ can be thwarted when the drawee decides not to sue its 


\section{in Code cases where the allocative rule of law does not fully reflect the cuipability scale. ${ }^{137}$}

\section{negligent customer.}

Creation of a cause of action by the depository bank against the drawer would bridge this gap in the Code provisions, and allow relevant deterrence and compensatory policies, indorsed by the legislature through enactment of the Code, to reach this situation.

\section{Id. at 1229-31.}

Similarly, the language of $\S 3-405(1)$ ("An indorsement by any person in the name of a named payee is effective if (a) ... an impostor . . . has induced the . . drawer to issue the instrument to him. ...") would seemingly place the loss resulting from an impostor upon the drawer even when another party negligently dealt with the impostor or paid the instrument. Nevertheless, courts have sometimes allowed the drawer to assert the payor bank's negligence. See, e.g., Owensboro Nat'l Bank v. Crisp, 608 S.W.2d 51 (Ky. 1980) (sufficient evidence of payor bank's negligence existed to warrant verdict in favor of drawer); Board of Higher Educ. v. Bankers Trust Co., 86 Misc. 2d 560, 563, 383 N.Y.S.2d 508, 511 (Sup. Ct. 1976) (drawer could assert bank's negligence in, among other things, failing to "verify her identity as the named payee" and allowing her to obtain "cash for several checks, made payable to different payees, at the same time"). See generally Comment, The Role of Negligence in Section 3-405 of the Uniform Commercial Code: Owensboro National Bank v. Crisp, 69 KY. L.J. 143 (1980-1981) (discussing rationale for distinguishing impostors from fictitious payees).

A final example is provided by $\S 7-204(1)$, which states:

A warehouseman is liable for damages for loss of or injury to the goods caused by his failure to exercise such care in regard to them as a reasonably careful man would exercise under like circumstances but unless otherwise agreed he is not liable for damages which could not have been avoided by the exercise of such care.

The warehouseman rather than the bailor would seem to be the lowest cost guarantor of the safety and security of goods in the warehouseman's possession. Thus, $\$ 7-204$ may be perceived as incorporating a loss allocation rule that omits the strict liability principle, although $\S 7-204$ 's omission is somewhat ameliorated by $\S 7-403$, which places the burden of establishing "damage to or delay, loss or destruction of the goods for which the bailee [the warehouseman] is not liable" upon the warehouseman. U.C.C. $\S 7-403$ (a), (b). In a prominent case, the court seized upon $\S 7-403$ 's language to insist that the bailee come forward with a more complete explanation for the disappearance of goods than that they had been stolen. See Proctor \& Gamble Distrib. Co. v. Lawrence Am. Field Warehousing Corp., 16 N.Y.2d 344, 359, 213 N.E.2d 873, 881, 266 N.Y.S.2d 785, 796 (1965). No matter how its opinion was articulated, the court substantially reinserted the strict liability principle into the allocation of loss rule applicable to bailees.

137. Description of this judicial tendency should not be interpreted as a criticism of what the courts have done, particularly where the omission of a principle seems more the result of accident than design. In the course of distinguishing between the external morality of law (the morality of its substantive provisions) and the internal morality of law (for example, its consistency and prospective orientation), Lon Fuller seemed to express some support for the tendency I have described:

The distinction between the external and internal moralities of law is, of course, a tool of analysis and should not be regarded as a substitute for the exercise of judgment. I have been at pains to show that along the spectrum occupied by these two moralities there may appear, in certain applications, a middle area where they overlap. . . . Suffice it for the present to point out that a judge faced with two equally plausible interpretations of a statute might properly prefer that which would bring its terms into harmony with generally accepted principles of right and wrong. Though this result may be rested on a presumed legislative intent, it can also be justified on the ground that such an interpretation would be less likely to make of the statute a trap for the innocent, thus bringing the problem within the considerations relevant to law's internal morality.

L. FULLER, supra note 106, at 132; see also id. at 205 (example of morality affecting judicial decision about entitlement under a will). While it is more difficult to condone judicial resurrection of the culpability scale in those contexts where the Code's drafters specifically intended a departure from the scale, the more important point (and the one that Fuller makes) is that substantive law should correspond to conceptions of right and wrong because, to the degree it does so, it will be more effective. 


\section{An Alternative Analysis: Retrospective Causation}

When liability is imposed according to the culpability scale, responsibility is tied to probability of loss. This nexus between risk and responsibility serves to deter loss from occurring in the first place. The culpability scale also corresponds with our moral sense of degrees of wrongdoing, and therefore of responsibility for harm. According to some theorists, however, deterrence and equity are most likely to be achieved by assigning responsibility according to a finding of who "caused" the loss. Thus, a comparison of the concepts of culpability and causation ${ }^{138}$ would be helpful in assessing the strength of the discussion in Part II of this Article. First, I will discuss the common ground and differences between the culpability scale and concepts of causation. Second, I will respond to scholars who have either posited an equivalence between moral blameworthiness and causation or who have concluded that imposition of liability based on causation best deters the occurrence of specified losses.

\section{A. Distinguishing Causation from Culpability}

Allocating responsibility for loss according to either culpability or causation theories requires factual determinations based on probabilities, but the perspectives of the two approaches differ. The culpability scale allocates loss to that party whose conduct was more likely than that of his commercial adversary to have increased the risk of loss. Its emphasis is

138. Twentieth-century literature concerning causation can be roughly divided into two broad groups: first, literature generally supportive of the importance of causation and characterized by attempts to formulate definite rules of causation, and second, literature generally denigratory of the importance of causation and disputative of the definiteness of such causation rules. The two have existed in a dialectical relationship.

The first group includes the legal formalists of the early twentieth century, most prominently Professor Joseph Beale of Harvard. See Beale, The Proximate Consequences of an Act, 33 HARV. L. REV. 633 (1920). By 1930, the group's influence had waned.

The second group includes such writers as Henry Edgerton, Leon Green, and William Prosser. See L. Green, Rationale of Proximate Cause (1927); W. Prosser, HaNdboOK of the LaW of TORTS $\$ \S 45-50$ (1941); Edgerton, Legal Cause (pts. 1 \& 2), 72 U. PA. L. REV. 211, 343 (1924). These men were strongly influenced by the writing of Judge Jeremiah Smith. See Smith, Legal Cause in Actions of Tort (pts. 1-3), 25 HARV. L. REV. 103, 223, 303 (1911-1912). All of these writers belonged to or were influenced by the realist movement, which aruse largely as a reaction to formalism and dominated legal literature for much of the twentieth century. See generally W. TWINING, KARL LLEWELLYN AND THE REALIST MOVEMENT (1973) (describing realist movement and Llewellyn's role within it). The literature of the formalists and the realists is directly relevant to the culpability scale, but its relevance goes to the question of whether it is coincidental that one finds the culpability scale in the Code. That issue is discussed later in this article. See infra pp. 280-86.

Modern writers, most prominently H.L.A. Hart and A. Honoré, have tried to resurrect causation. See H.L.A. HART \& A. HONORE, CAUSATION IN THE LAW (1959). Their ranks most recently include John Borgo, Guido Calabresi, Richard Epstein, Mario Rizzo, and Steven Shavell. See Borgo, Causal Paradigms in Tort Law, 8 J. LEGAL STUD. 419 (1979); Calabresi, supra note 128; Epstein, A Theory of Strict Liability, supra note 105; Epstein, Intentional Harms, supra note 105; Epstein, supra note 129; Rizzo \& Arnold, supra note 115; Shavell, An Analysis of Causation and the Scope of Liability in the Law of Torts, 9 J. LEGAL STUD. 463 (1980). 
prospective: The determination is based on the actor's state of mind or position before the actual occurrence of the event causing loss. Once relative culpability is established, greater causal responsibility follows as a matter of law. Although the litigation that follows a loss serves to allocate that loss, its more important function is the instrumentalist goal of deterring conduct that may cause such losses.

Causation, particularly in the guise of the "but-for" standard, ${ }^{139}$ instead takes a retrospective approach. It focuses on the probability that an act has produced a given consequence. The aim of litigation in which causation is the determinative issue seems more compensatory than instrumentalist.

In most cases, determining responsibility for loss using either theory-causation or culpability-should produce the same results. Because allocation of loss according to culpability reflects the degree of risk that the prospective actions of two commercial parties engendered, loss will usually occur as might have been predicted ex ante. The theories will produce different results, however, in two contexts. First, isolated random variables might account for the loss. Where random variables account for a difference, allocating loss on the basis of the culpability scale can be perceived as reflecting a preference for relating responsibility to recurring variables. ${ }^{140}$ Second, a difference in the determination of liability might occur if certain recurring variables, other than the mental state or positions that the culpability scale recognizes, are considered. For example, the size or skill of the parties might affect their relative abilities to avoid a particular risk. ${ }^{141}$ Significantly, the Code departs from the culpability

139. See W. PROSSER, supra note $138, \S \S 451-505$.

140. Suppose, for example, that a manufacturer negligently produces some goods, and that after the risk of loss has passed to the buyer, the goods are destroyed by an earthquake or other act of God. The question arises whether it is the manufacturer or buyer who must bear the loss. If stress is laid on the manufacturer's culpability (a recurring variable in the context of sales transactions), it is the manufacturer who should bear the loss: Negligent manufacturers substantially increase the risk that losses will be suffered in sales of goods transactions. Assuming that the goods are uninsured, this is the result achieved by U.C.C. $\$ 2-510(2)$ ("Where the buyer rightfully revokes acceptance he may . . . treat the risk of loss as having rested on the seller from the beginning."); see also id. \$ 2-510(3) (effect of buyer's breach of contract on risk of loss). In contrast, if the focus of the legal rule were the earthquake (a random variable in the context of sales transactions) as the predominant "cause" of this particular loss, the buyer would have to bear the full loss. It would not matter that the negligence of manufacturers generally increases the risk of loss in sales transactions because, in this particular instance, the manufacturer's negligence was irrelevant. Nor would it matter that the legal rule, if it emphasized the earthquake as the "cause," would neither reduce the level of earthquakes nor increase care on the part of manufacturers. The thrust of such a rule would be retrospective, not prospective.

141. See Unico v. Owen, 50 N.J. 101, 232 A.2d 405 (1967) (skill and size of financiers of consumer transactions compared with consumers justifies placing risk of seller's nonperformance on financier). Factors such as size, wealth, and expertise might allow one commercial party to pool risk better than another and therefore dictate allocation of risk to that party, regardless of the other's negligence. See K. ARROW, ESSAYS IN THE THEORY OF RISK-BEARING 136 (1974). Nevertheless, departures from the culpability scale, even on the basis of such factors, must be made cautiously. Allocation of risk to the larger and putatively more expert pooler of risk might itself increase the level of risk 
scale in a limited number of cases where it appears that the parties differ in their ability to deter risk in a manner unrelated to culpability. ${ }^{\mathbf{1 4 2}}$

One should not assume that a particular legal doctrine must incorporate either culpability or causation to the exclusion of the other. Much legal doctrine, at least in the Code, contains both culpability and causation issues, although the phraseology of the doctrine may stress one issue over the other. For example, to shift the loss resulting from alterations and unauthorized signatures pursuant to section 3-406 requires proof of both "negligence," a culpability issue, and "substantial contribution," a causation issue. ${ }^{143}$ When a particular legal doctrine incorporates both culpability and causation-in-fact, the two subdoctrines stand as hedges against exclusive reliance on either proof directed toward the probability of what would happen to the exclusion of proof of the probability of what did happen, or on the converse. Legal rules that incorporate both culpabilty and causation-in-fact require the factfinder to determine both the anterior probability ${ }^{144}$ of the actor's causal responsibility for loss, considering culpability alone, and also the posterior probability ${ }^{145}$ of causal responsibility, considering evidence of other factors. Unless both anterior and posterior probability judgments point in the same direction, the elements of the legal doctrine are not satisfied.

The difference in perspective between culpability and causation narrows considerably if we conceive of causation in more than a but-for phys-

because there would be less incentive for others to be careful. Economists term this phenomenon the "moral hazard." One response by insurers, who by definition bear risk because of size and expertise incidental to pooling risk, has been coinsurance. See id. at 134-49. Professor Priest has recently usefully applied the concept of moral hazard to consumer product warranties. See Priest, $A$ Theory of the Consumer Product Warranty, 90 YALE L.J. 1297 (1981). Similarly, one can perceive allocation of loss according to the negligence principle as responsive to the moral hazard problem and therefore functionally equivalent to a coinsurance clause.

More problematic than overriding the strict liability principle with the negligence principle is the soundness of the legislative efficiency calculation that underlies the strict liability principle. That calculation, based on the positions of the parties, may not have included all the inputs relevant to risk bearing, such as pooling capacity. On the other hand, it is not at all clear that pooling capacities between commercial parties presently differ as much as they once might have. Computers have now facilitated information flow to an extent that commercial parties to whom the risk has been allocated on other than superior pooling grounds can join with other similarly situated parties and collectively share the risk allocated to them.

142. One case in which the Code departs from the culpability scale is where the original owner of goods has been defrauded and the purchaser of the goods from the defrauder is not a merchant. Even if facts about his transferor's fraud abound, the purchaser will win over the true owner as long as the purchaser lacked actual knowledge of the fraud perpetrated upon the true owner by the transferor. See U.C.C. § 2-403. This is because the "good faith" requirement of a nonmerchant is subjective, demanding only "honesty-in-fact." Id. $\S 1-201(19)$; see supra note 18 . Thus, the rule that allocates loss in this particular context omits the negligence principle.

143. See infra pp. 281, 285-86.

144. Anterior probability, as used in the text, is the probability assigned to a particular event or risk prior to the time it actually happens.

145. Posterior probability, as used in the text, is the probability assigned to possible causal factors after loss has occurred. 
ical cause-and-effect sense. Certain scholars, including Hart and Honoré, ${ }^{146}$ and more recently Borgo, ${ }^{147}$ have proposed a "context-related" causation that achieves this narrowing. To them "cause" is the factor an average person would consider most responsible for the act in question. ${ }^{148}$ The ordinary person would look at the mens rea or position of the actor in determining causation; ${ }^{149}$ therefore, the context-related causal theorists may be said to have incorporated the culpability scale into the concept of causation. ${ }^{150}$

The primary way in which context, and especially the actors' mental position, is considered part of legal cause is through the proximate cause

146. See H.L.A. HART \& A. HONORÉ, supra note 138, at 24-57.

147. See Borgo, supra note 138 , at $432-40$.

148. See H.L.A. HART \& A. HONORÉ, supra note 138, at 1 (law is concerned with "the plain man's notions" of causation); id at 86 (stress laid upon "the ordinary man's stock of general notions"); Borgo, supra note 138, at 432 (of "all of the factors necessary for the production of a harm," only some are entitled to be considered causes "as a matter of ordinary language").

149. See H.L.A. HART \& A. HONORÉ, supra note 138, at 38-41, 129, 131; Borgo, supra note 138 , at $439,443,447$.

150. This de facto incorporation of the culpability scale into causation leads to considerable confusion in Hart and Honoré's discussion because, while accepting causation, they reject risk and morality as the primary grounds for determining legal responsibility. See H.L.A. HART \& A. HONORE, supra note 138, at 230-60. To Hart and Honoré, the central concept of causation

is that of a contingency, usually a human intervention, which initiates a series of physical changes, which exemplify general connexions between types of event; and its features are best seen in the simplest cases of all where a human being manipulates things in order to bring about intended change.

Id. at 2 (emphasis added). Hart and Honoré thus tender as their most indisputable instance of cause and effect an example that includes a violation of the intention principle, the culpability scale's first element.

Suppose that the physical act that ultimately results in harm is not intentional; for example, a manufacturer negligently manufactures a product. If the purchaser violates the knowledge principle, would Hart and Honoré consider the negligent manufacturer or the knowing purchaser to have been the cause? They state:

An act done without knowledge or appreciation of the circumstances does not negative causal connexion. For instance, the act of a consumer who uses a product without knowing that it is defective will not bar an action against a negligent manufacturer, whilst the consumer's knowledge of the defect will bar recovery at any rate if he is not compelled to use the thing in any case.

Id. at 141 (emphasis added). Their perception that knowledge will negate causal connection, even when the first party acted negligently, is simply another way of expressing the primacy of the knowledge principle over the negligence principle.

It might be supposed that Hart and Honoré's distinction between voluntary and involuntary conduct and their willingness to rest legal responsibility on the former, but only sometimes on the latter (when there is no intervening voluntary conduct) would lead to a recognition that they have tied legal responsibility to probability of harm. Yet they fail to accept the positive correlation between intention and risk: "The mental attitude of the actor would not make his act more or less dangerous; so no doubt mental attitude is a non-causal element in fault." Id. at 215.

Significantly, they also shy away from tying their causal system to a moral appraisal: "[T]he causal description of the cause does not turn on the moral appraisal of A's action or the wish to punish it." Id. at 73.

Although John Borgo does not explicitly deny the relevance of risk, he never distinguishes between probability of cause anterior to the loss-causing act or event and probability afterwards. Rather, his methodology for identifying "cause" is to analogize fact patterns to certain causal paradigms. See Borgo, supra note 138. 
standard. The central tenet of proximate cause is that liability and damages are imposed on a party when they were foreseeable by the party. ${ }^{151}$ So stated, proximate cause and culpability seem to be different ways of focusing upon the same considerations. Intention, knowledge, negligence, and the judgment about relative abilities to avoid loss with least cost that underlies strict liability are gradations in the relative abilities of actors to foresee risk and therefore to avoid injury. ${ }^{162}$ Inclusion in legal doctrine of either the proximate cause requirement or a culpability standard evinces a reluctance on the part of lawmakers to allocate responsibility solely on the basis of a finding of "but-for" causation. Both seem oriented toward deterrent as well as compensatory functions of law. ${ }^{163}$

The shared focus of proximate cause and culpability, however, should not obscure significant differences between the two. When foreseeability is handled explicitly as an aspect of culpability, the boundaries of factfinding can be precisely and narrowly drawn by courts and legislatures. In contrast, when foreseeability is treated as a factual issue determinative of proximate cause and therefore of causation, the factfinder's scope of determination is broader. In those cases, a jury will often be the factfinder; such doctrine therefore strengthens the role of the jury in comparison with the judiciary. This institutional difference may mean that cases tried under causation principles will show a wider range of outcomes than those tried under the culpability scale. ${ }^{154}$ Whatever the merits for doing

151. See Calabresi, supra note 128. For Prosser's definition of "proximate cause," see W. ProsSER, supra note $138, \S 45$, at $311-20$.

152. For example, the party who creates the situation giving rise to the loss has clearly foreseen it more than another who merely was negligent in not perceiving it. Foreseeability has been actualized where either intention or knowledge are present; foresight is still incipient where an actor simply occupies the position of the lowest cost loss avoider. The negligent actor stands between these positions.

153. The similarity between the underpinnings of the proximate cause standard and those of the culpability scale raise the question of why the two coexist in our legal culture. The most likely answer is that both the proximate cause standard and the culpability scale are hedges against the possible failure of either to promote the policies that they jointly embrace. These policies, which stand in opposition to responsibility tied to causation-in-fact, are so important that lawmakers have in effect diversified against the risk that responsibility would be tied to causation-in-fact. If this explanation is true, it would add considerable support to the conclusions of scholars such as Richard Posner and Paul Rubin, who have argued that judicial as well as legislative lawmakers have stressed the related goals of efficiency and deterrence more than is commonly accepted by those who take issue with the law and economics literature. See R. POSNER, supra note 105; Rubin, Why is the Common Law Efficient?, 6 J. LEGAL STUD. 51 (1977).

Another possible reason is that while the culpability scale incorporates a moral dimension as well as an assessment of risk, the proximate cause standard includes the latter only. The fact that no moral basis is claimed on behalf of the proximate cause standard, however, does not mean that this standard fails to incorporate one. Undertaking an action when certain damages are foreseeable is more selfish than engaging in the same conduct when damages are not foreseeable. Consequently, the conclusion that the actor is liable for damages in the former instance but not in the latter accords with our moral sense as to the appropriate scope of responsibility for one's actions.

154. One of the foremost critics of the jury system on this very ground was Jerome Frank. See, e.g., J. FRANK, COURTS ON TRIAL 108-25 (1949); J. FRANK, LAW AND THE MODERN MIND 177-78 
so, the factfinder might even allocate loss according to the relative wealth of the contesting parties.

Thus, the assertion that the culpability scale is another means to approach causation, while broadly correct, overstates the relationship. A more accurate view is that liability tied to culpability is a substitute for, or a counterweight to, liability tied to causation, whether legal cause is defined in a physical or contextual sense. To the extent that the culpability scale is emphasized, less room in the decisionmaking process is reserved for causation as the most relevant and important issue determining responsibility for loss. Conversely, to the extent that culpability is deemphasized, the focus on causation widens, sometimes to the exclusion of almost all other issues. ${ }^{185}$

\section{B. Causation and Morality}

Richard Epstein has asserted that a legal system that allocates responsibility according to who "caused" a loss-a system he terms one of "corrective justice"-is ethically superior to other allocative systems. ${ }^{158}$ This leads him to prefer strict liability in tort, which he interprets as almost wholly explicable in terms of four causal paradigms, ${ }^{167}$ rather than negligence, which he views as based upon utilitarian rather than causal considerations.

Despite Epstein's adherence to causation as the positive and normative linchpin of tort law, it is unclear whether he would take issue with my contention that allocation of commercial loss according to the culpability

(1930). Frank in turn profoundly influenced Karl Llewellyn, the chief drafter of the Code. See Llewellyn, Some Realism About Realism-Responding to Dean Pound, 44 HaRV. L. REV. 1222 (1931) (in a note on the title page, Llewellyn tried to attribute coauthorship to Frank).

155. This seems to be the case with respect to some interpretations of strict liability in tort. See, e.g., Epstein, supra note 129; Epstein, A Theory of Strict Liability, supra note 105.

156. See Epstein, Causation and Corrective Justice: $A$ Reply to Two Critics, 8 J. Legal STUD. 477 (1979) [hereinafter cited as Epstein, Causation and Corrective Justice]; Epstein, Nuisance Law: Corrective Justice and Its Utilitarian Constraints, 8 J. LEGAL STUD. 49 (1979); Epstein, supra note 129; Epstein, A Theory of Strict Liability, supra note 105. Certain other scholars, although they do not necessarily agree with Epstein's concept of causation or his interpretation of corrective justice, have also posited the ethical superiority of a system that bases responsibility for harm upon a factual finding of who caused it. See Borgo, supra note 138. For a criticism of these theories, see Posner, The Concept of Corrective Justice in Recent Theories of Tort Law, 10 J. LEGAL STUD. 187 (1981) [hereinafter cited as Posner, Corrective Justice]. Posner specifically criticizes Epstein's perspective in Posner, Epstein's Tort Theory: A Critique, 8 J. LEGAL STUD. 457 (1979) [hereinafter cited as Posner, $A$ Critigue]; Posner, Strict Liability: A Comment, 2 J. LEGAL STUD. 205 (1973) [hereinafter cited as Posner, Strict Liability]. My analysis in the text differs from Posner's criticism of Epstein in that I focus specifically upon the reasons why Epstein's arguments, if applied to commercial law, do not negate but in fact support the ethical foundation of the culpability scale.

157. Epstein's four causal paradigms are: (i) force, illustrated by " $A$ hit $B$," Epstein, $A$ Theory of Strict Liability, supra note 105, at 166-71; (ii) fright and shock, illustrated by " $A$ frightened $B$," id. at 172-174; (iii) compulsion, illustrated by " $A$ compelled $B$ to hit $C$," id. at 174-77; and (iv) dangerous conditions, illustrated by " $A$ created a dangerous condition that resulted in harm to $B$," id. at 177-89. 
scale corresponds best to our moral sense. Epstein expressly confines his analysis to the field of torts, not commercial law, and specifically to "cases of physical injury." 158 Moreover, his writings reflect a legal landscape in which negligence and strict liability are considered substitutes for, rather than complements of, each other. His assumption is that if a defendant is sued on negligence grounds and negligence is not proved, the defendant who caused the plaintiff's injury is exculpated. This assumption does not apply to the culpability scale, despite its incorporation of a negligence principle. If a defendant is not proved to have been negligent, the culpability scale does not necessarily relieve him of liability for loss. The culpability scale would then dictate an allocation of loss in accordance with the strict liability principle. The same defendant who is not found liable on negligence grounds might be held responsible for the loss because, by virtue of his position, he was the least costly risk avoider.

Nevertheless, Epstein's discussion seems relevant to my analysis and requires a response for several reasons. First, the reader might be tempted to equate morality and causation in commercial law even though Epstein himself does not press this linkage outside the field of torts. Second, distinctions between substantive areas of the law such as commercial law and torts are, in many respects, artificial (the forger has clearly committed a tort, albeit a commercial tort) and, at the margin, impossible (for example, Epstein discusses the case of the buyer of a product who is injured, or whose property is injured, by the seller's defective product ${ }^{159}$ ). Finally, Epstein's writings can be and have been interpreted to bar a defense of contributory negligence in an action based upon strict liability in tort, ${ }^{160}$ a

158. Epstein, A Theory of Strict Liability, supra note 105, at 165.

159. Id. at 178 .

160. Posner sees a "strong implication [in Epstein's writings] that no version of contributory negligence will be permitted." Posner, Strict Liability, supra note 156, at 220. Posner's reading of Epstein is easy to understand. In $A$ Theory of Strict Liability, when he discusses the paradigm of dangerous conditions-a paradigm that includes the case of defective products-Epstein states:

[The plaintiffs] carelessness might be regarded as sufficient to support the defense of contributory negligence. The acceptance of contributory negligence as a defense is natural in a system that presupposes that the plaintiff must allege negligence in order to complete his prima facie case. But let the defendant's negligence be regarded as immaterial to the prima facie case, and it is then difficult to see why the plaintiff's negligence should raise a valid affirmative defense.

Epstein, $A$ Theory of Strict Liability, supra note 105, at 181. Epstein reinforces the impression that he would not allow the defense of contributory negligence by adding "that the allegation of carelessness by the plaintiff does not affect the judgment that the conduct of the defendant was, under the paradigm of dangerous conditions, the cause of the harm in question." Id. If he had so wanted, Epstein could have dispelled the plain meaning of the quotations in his next article, Epstein, supra note 129 , where an avowal of an intent to bar the defense of contributory negligence would have been most appropriate, but he failed to do so. At most, the reader of this article, Defenses and Subsequent Pleas, might gain an impression that some of the conduct that is traditionally the basis of the contributory negligence defense might be the subject of a "causal defense" or "assumption of risk" defense, which Epstein would permit even in an action based on strict liability. However, in response to Posner's criticism, and several years after his first two articles on the subject, Epstein wrote:

In dealing with incentive, Posner notes that my system does not recognize any contributory 
result that contradicts the culpability scale's allocation of loss.

Epstein argues that a causation-based system of responsibility for harm better safeguards "individual liberty"161 and provides a more "coherent set of rules"162 than a fault-based system of responsibility. In addition to these arguments, Epstein levels two charges specifically at the "reasonable man" standard of a negligence system: its imprecision ${ }^{\mathbf{1 6 3}}$ and its characteristic as an "external standard." At least in the context of commercial transactions, however, these criticisms support culpability, not causation, as the primary basis for allocating loss. Arguably, the specifics of Epstein's criticisms reveal that, despite the "causation" label he applies to his system of corrective justice, even Epstein bases responsibility on culpability rather than causation.

Consider, first, Epstein's reference to notions of human liberty. When one person is "the non-reciprocal source of the harm"10s to another, the actor has surpassed his liberty and infringed on that of the injured. ${ }^{168}$ Epstein's first causal paradigm is " $A$ hits $B$. "167 Because $A$ as the subject has caused harm to $B$ as the object, $B$ has a cause of action against $A$. According to Epstein, his three other paradigms, based on fright, compulsion, and dangerous conditions, all similarly partake of the quality of one party "[using] . . . force . . . against the person or property of another."188 $A$ as the subject causes harm to $B$ as the object, directly or indirectly.

Because Epstein illustrates rather than defines causation, the reader

negligence defense. The point is true but wholly misleading, since I incorporate a defense of contributory causation (to give it a much needed label) that is in all respects broader than contributory negligence. Contributory negligence is a defense that requires the defendant to establish both the plaintiff's want of reasonable care and the causal connection between the plaintiffs conduct and his own harm. Contributory causation dispenses with the first limitation but preserves the second. It creates therefore a situation in which, at the very least, careless plaintiffs are barred from recovery just as they are under contributory negligence.

Epstein, Causation and Corrective Justice, supra note 156, at 493-94.

My point in the text, of course, is not that Epstein would necessarily bar such a defense. It is, rather, that given the fact that at least one prominent scholar so interprets Epstein and that other scholars might do so, and given the fact that failure to recognize such a defense in commercial contexts violates the culpability scale, a response on my part is appropriate.

161. Epstein, A Theory of Strict Liability, supra note 105, at 203.

162. Epstein, supra note 129 , at 215 .

163. Id. at 181 .

164. Id. at 184. By external standard, Epstein means that the actor's conduct is measured against the standard of what a "reasonable man" would have done. Since the actor's own characteristics (for example, intelligence) may not correspond with those implicit in the reasonable man standard and since, also, a direct comparison between the actor's and his adversary's conduct is avoided, the standard is considered "external" to the parties.

165. Epstein, A Theory of Strict Liability, supra note 105, at 168-69.

166. Epstein states: "In effect, the principles of strict liability say that the liberty of one person ends when he causes harm to another." Id. at 203-04.

167. Id. at 167.

168. Epstein, Causation and Corrective Justice, supra note 156, at 481. 
must discover for himself why it is that even with respect to Epstein's most basic paradigm of force, $A$ is the "cause" of harm to $B$, rather than vice versa. Obviously both are necessary conditions to the injury, as Epstein well recognizes. One possible interpretation is that $A$ can be differentiated from $B$ because $A$ initiated the interaction between the two. In short, causation is time based. But it would be too simplistic to apply such a subject-object, time-based analysis to commercial contexts. Where loss resulting from a forged check must be allocated and the forger has disappeared, who should be deemed to have acted first: the bank that printed the checks, the customer whose checks were stolen, the person who took from the forger, or the bank that paid the instrument over the forgery? Even in the context of tort law, Epstein seems aware of the pitfalls of basing causation and hence responsibility solely on the time-sequence of the parties' actions, and he rejects that procedure. ${ }^{\mathbf{1 6 9}}$

Another possible source of differentiation between $A$ 's and $B$ 's conduct is that $A$ has chosen to act in relation to $B$, but $B$ has not chosen to act in relation to $A \cdot{ }^{170}$ Yet choice, unless it is used in the sense of culpability as developed in this Article, also fails as a method of imposing liability in commercial contexts. ${ }^{171}$ In the commercial field, both parties have "chosen" to enter the stream of commerce with the risks that it entails, and, more particularly, to engage in that transaction that gives rise to the suit. This includes, for example, the bank that handles and pays negotiable instruments and the customers who draw the instruments. Or to use another example, both the manufacturer and the user of a defective product have "chosen" to engage in the transaction, the former as seller and the latter as buyer. Unless one of them has violated the intention or knowledge principle, neither one knows the product is defective or would choose to make the product defective, yet both are unwilling to pay the price of a risk-free world.

169. In illustrating appropriate and inappropriate usages of his paradigm of dangerous conditions, Epstein presents the following example: " $H$ leaves her carving knife in her kitchen drawer. A thief steals the knife and uses it to wound $I$. Has $H$ caused $I$ harm in any sense of the term? . . . The answer to . . . [this] question . . . is no." Epstein, A Theory of Strict Liability, supra note 105, at 179.

170. Epstein's rejection of private necessity and compulsion as defenses in an action based on strict liability in tort indicates that choice does play a large role in his scheme:

Consider the situation where the defendant, when faced with ... external threats-a severe storm, or an attack by a third party . . . inflicts harm upon the plaintiff . . . . The argument here is only that it is fairer to require the defendant to bear the loss because he had the hard choice of harming or being harmed when ... the plaintiff had no choice at all.

Epstein, supra note 129, at 169.

171. Posner, for one, does not seem to think Epstein's subject-object dichotomy, whether based on time or choice, has much merit in tort law either. See Posner, A Critique, supra note 156. Nor would Coase agree that the conduct of two parties in a tort context is nonreciprocal, especially in the context of Epstein's paradigm of dangerous conditions. See Coase, The Problem of Social Cost, 3 J. L. \& ECON. 1, 2 (1960). 
Epstein's use of linked, nonreciprocal conduct ${ }^{172}$ to make an ethical judgment about two actors is a valid insight. But neither time-sequence nor choice, without connection to a concept of culpability, constitutes a satisfactory source of such linked, nonreciprocal conduct. A better source, of course, is choice or volition as used in the sense of culpability. Epstein himself recognizes a violation of the intention principle as the most egregious case of one person violating the human liberty of another-in other words, as the most unethical of all conduct. ${ }^{173}$ Epstein also approves of assumption of risk as a defense to an action based upon strict liability in tort. ${ }^{174}$ By Epstein's own admission, the validity of the defense of assumption of risk does not rest on "causal principles."178 Culpability, not causation, explains the defense. Epstein's approval of an assumption of risk defense amounts to his recognition that a knowledge principle exists and that violation of the knowledge principle is more culpable than mere violation of the strict liability principle.

It seems, therefore, that Epstein does recognize a role for culpability in a system of tort loss allocation. Even so, there are two major differences between the commercial culpability scale articulated in this Article and the culpability scale used by Epstein. First, the former is explicit (on my part, at least) while the latter is implicit. Second, the commercial culpability scale includes a negligence principle, while Epstein's scale does not. With these differences in mind, it is now possible to respond to Epstein's other arguments in favor of a causal rather than fault-based liability system.

Epstein argues that a causation-based system "enables us . . . to fashion a coherent set of rules . . . that should lie at the heart of any system of tortious responsibility." ${ }^{178} \mathrm{He}$ tries to demonstrate this by means of a

172. Epstein, A Theory of Strict Liability, supra note 105, at 167.

173. Epstein states: "The element of intention makes the case an easy one, by allowing loss to be placed upon the person who willed it, upon the person who is 'bad' in the strongest sense of the word." Epstein, Intentional Harms, supra note 105, at 391; see also Epstein, Causation and Corrective Justice, supra note 156, at 485-86 (describing examples of violations of the intention principle, with the violator bearing the loss).

174. Epstein illustrates the defense with the following example:

Take the case where a man stops on the street to watch a baseball game, or perhaps a display of fireworks; or the case where he runs in front of a moving train in order to save his own property, or perhaps the life of a small child. In each of these cases . . . it should be possible to make out the defense. . . on the ground that the plaintiff decided that he would take the risk of a known and perceived danger in order to pursue some objective of his own.

Epstein, supra note 129 , at 187.

175. Id. at 185. It should be added that Epstein is correct only if one views "causal principles" as retrospectively based upon what actually happened (as Epstein professes to do) rather than prospectively based upon what was likely to happen, that is, the probability of harm (as I do). See supra pp. 255-56.

176. Epstein, supra note 129, at 215. In much of his discussion, Epstein seems to equate coherence with "a single conceptual framework," id. at 169 , that is, with the characteristic of enabling the lawmaker to identify both appropriate claims and defenses solely by reference to his conceptual spoke, 
system of pleas and counterpleas. Initially the plaintiff must prove "the non-reciprocal source of the harm . . . to upset the balance where one person must win and the other must lose."177 At that point, the defendant must provide a defense, if he has one. ${ }^{178}$ The plaintiff can then reply to this defense, and the process will continue until the issue is drawn. Yet, Epstein's arguments hardly demonstrate the coherence of a system based only on causation. The system is not coherent in the sense that it can avoid referring to principles other than its driving force, causation. Once Epstein admits that defenses, such as assumption of risk, can be noncausally based, ${ }^{179}$ reference to considerations such as culpability to determine whether a defense should be permitted becomes inescapable.

Nor is Epstein's system superior in the sense of being more capable of isolating separable issues than alternative systems. Because culpability largely underlies Epstein's concept of cause, questions of wrongful conduct, harm, and linkage between the parties are intertwined. ${ }^{180}$ Epstein correctly levels much the same charge at the "proximate cause" standard, ${ }^{181}$ but fails to recognize that his own concept of cause is subject to the same infirmity. Yet, rather than extracting and confronting culpability as a separate issue, thereby demoting causation to a rather minor role in the allocation of loss, Epstein relies upon causation almost exclusively. The trier of fact is left to wander in a wilderness that lacks even the "proximate cause" standard's insufficient guidance. ${ }^{\mathbf{1 8 2}}$

Epstein specifically criticizes the negligence "reasonable man" standard for its imprecision and its externality to the parties involved. These criticisms of negligence support only by implication what Epstein perceives as a causation-based strict liability system. In order to determine whether Epstein's system, if applied in commercial contexts, would avoid the imprecision and externality of the negligence standard, it is useful to compare a culpability scale that includes the negligence principle, such as that articulated in this Article, to one that excludes negligence, such as the one that Epstein implicitly adopts when his causal paradigms, defenses, and explanations are considered together. In short, when, if at all, does recog-

\footnotetext{
"cause." At other times, Epstein at least implies that he bases the superior coherence of a causal system on its characteristic of enabling the factfinder to sort out and to decide the necessary issues. My response in the text following this note takes account of both possible usages of the phrase "coherent set of rules."

177. Epstein, A Theory of Strict Liability, supra note 105, at 168-69.

178. See generally Epstein, supra note 129 (discussing effectiveness of various defenses).

179. Id. at 185-201.

180. Posner makes much the same criticism: "[I]n not making this distinction [between wrong and injury] explicit Epstein merges the issues of wrong and injury, with the result that the ethical basis of his system is unclear." Posner, Corrective Justice, supra note 156, at 196.

181. Epstein, A Theory of Strict Liability, supra note 105, at 161-63.

182. See supra p. 268.
} 
nition of negligence matter?

In general, the negligence principle is material when there is another party that, in the absence of the negligence principle, would bear the loss under the strict liability principle. The negligent party may be bearing a loss that it seeks to shift to another on the basis of strict liability, or another party may seek to shift the loss to the negligent party. In one instance, the allegedly negligent party is a plaintiff; in the other, a defendant.

Suppose, first, that the allegedly negligent party must bear the loss, unless he can by, legal rule shift it to another. Consequently, the negligent party sues the party who would bear the loss under the strict liability principle. In this context, the negligence principle, if accepted, would be asserted as a defense. For example, the negligent purchaser of a product sues the seller of the product, who in the absence of the purchaser's negligence would be considered the least costly avoider of product defects and therefore liable under the strict liability principle. Or, the negligent drawer of a check whose signature is forged sues the payor bank, which is considered the least costly avoider of such forgeries and therefore required to bear the resultant loss under the strict liability principle. If a negligence principle is recognized, the negligent purchaser and negligent drawer are stuck with their losses. ${ }^{183}$

Application of Epstein's causal-based system would also seem ${ }^{184}$ to allow the manufacturer and the payor bank a possible defense. But the theory of this result would be that the product user or drawer was "contributorily causal" rather than "contributorily negligent."188 This verbal change, which may or may not be substantively significant, has several drawbacks. First, where the product purchaser or drawer acted unreasonably, Epstein's verbal formulation of the defense, unlike contributory negligence, fails to make clear that the loss is being allocated to that party because he unreasonably increased the risk of doing business to a degree that, if others acted similarly, society could not tolerate. ${ }^{186}$ Second, it leaves open the possibility that the non-negligent product user or drawer of a check will be forced to bear the loss based on the defense of causal contribution, even though the manufacturer is the least costly avoider of product defects and the payor bank of forged drawers' signatures. For example, the product purchaser uses his product, the immediate act that results in harm, and the drawer leaves his blank checks in an unlocked

183. See supra pp. 235, 247-48.

184. It is not crystal clear in Epstein's writings that he would allow the manufacturer and the payor bank to assert their defenses. See supra note 160 .

185. See id.

186. See supra p. 254. 
desk drawer. If these are considered causes for purposes of the causal contribution defense, then the law is discouraging plainly desirable commercial activity for no good reason. If these are not considered "causes," the question becomes "why not." Either we are thrown back to inadequate time-sequence or cause-without-fault bases, or we fall back to a culpability explanation, and fault becomes the criterion of choice as to whether an act that obviously has contributed to the harm is or is not to be considered a "legal cause" of it. Imprecision in the negligence standard is not eliminated, but merely hidden.

There is one way to try to avoid a reference to fault, namely, to treat the actions of both parties-the product purchaser and the manufacturer, or the drawer and the payor bank-as causes, and to apportion the loss according to their respective causal contributions. Yet even if one could do so without reference to culpability, this resolution would not be precise enough to avoid the charge of vagueness that Epstein levels at the common law negligence system. Or, one could simply apportion the loss evenly between the two (or more) actors who causally contributed to the harm. ${ }^{187}$ But this resolution, despite its precision once the hurdle of identifying causal contributants is overcome, hardly is "just" or "ethical" on the basis of any readily apparent principles. Because this suggestion is so arbitrary, it is a standard that is as "external" to the actual facts of the parties as one could suggest.

Suppose, next, that it is the party who would bear the loss according to the strict liability principle who is initially stuck with the loss. He seeks to reallocate that loss to a negligent party. If a negligence principle is recognized (as it generally is under the Code), the residuary loss bearer at least has the opportunity of shifting the loss to the more culpable commercial party, based on the facts of the particular case. True, the negligence principle involves some imprecision, but the imprecision is tolerable considering the number of similarly situated commercial actors whose existence and conduct provide good evidence to establish the standard of conduct that would satisfy the negligence principle. For example, in the case of a drawee bank, it is "the reasonable commercial standards of the drawee's . . . business,"188 or in the case of a merchant, it is the "reasonable" com-

187. Epstein seems to suggest this resolution:

[I]n the case where A places a large boulder on the edge of the cliff, which is then pushed over the side by $B$, where it falls upon $C$ below . . . we can first sort out the priority between $A$ and $B$ in those cases in which only causal elements (i.e., the case of two innocent actors) are involved. Here there is no clear pattern of domination between A and B as in the case of $A$ compelling B to hit $\mathrm{C}$. There is no good answer on causal priorities, since A only facilitated B's conduct. Perhaps therefore, an even division might be the best rule, if only for administrative convenience.

Epstein, Causation and Corrective Justice, supra note 156, at 485 (emphasis added).

188. U.C.C. § 3-406. An external standard is also implicit in the effect the Code gives to a "usage 
mercial standards and "skills" of people in the trade. ${ }^{189}$ And although the negligence standard is necessarily external in that it is objective, the negligence principle mitigates the even more externally based strict liability principle. Whereas the external negligence standard is usually a model of behavior of a reasonable person in the circumstances of the relevant actor, the external strict liability standard is a model of behavior that one class of actors can observe at less cost than another class of actors. ${ }^{180}$ As between the negligence and strict liability principles, then, the latter brings to bear external factors more removed from the actual facts. If an external standard is to be applied, it seems fairer to apply a negligence standard, which at least takes account of the conduct of the contesting parties, rather than a strict liability principle based upon an efficiency calculation, which considers only their positions. The position of the parties may be the only factor the decisionmaker has to rely on, but at least loss should be allocated on that basis only after one party has had the opportunity to prove that the other party has acted more culpably.

Arguably, the strict liability principle could be made less externally oriented by allowing courts to allocate the loss on an ad hoc basis to that party who could have avoided it with least cost, regardless of the class of actors to which the party belongs. But it is not clear that courts are properly equipped to undertake that kind of inquiry. They are certainly less familiar with it than with the inquiry required to determine if a party has acted reasonably under the circumstances. Even if that objection is surmounted, the inquiry into relative efficiencies would hardly be "precise."191

Indeed, if the statutory classification necessary to allocate loss according to the strict liability principle is retained, the very flexibility of the negligence concept can be advantageous. The negligence standard allows a

of trade," see id. § 1-205(2), and clearing house rules applicable to banks, see id. $\S \S 4-103(1),(2), 4-$ 202.

189. The theme of reasonableness according to commercial practices pervades article 2. See, e.g., id. $\S \S 2-103(1)(b), 2-104(1)(3), 2-201(2)$.

190. As with the drawee bank that bears the residual loss if it pays out a check on which the drawer's signature has been forged, however, the model of behavior may be neither typical of nor generally desirable on the part of members of that class. See supra p. 242 . The statutory judgment is simply that if deterrent measures are to be implemented, members of that class could generally do so at a comparatively lower cost than members of another commercial class.

191. One further possibility is to try to implement a causally based system with the strict liability principle based not upon who could have avoided the loss with least cost, but who in fact most caused the loss. This resolution would be even more imprecise and arbitrary in that it would leave "cause" completely undefined. It would be subject to the same criticisms made in the context of the hypothetical having the allegedly negligent party as the plaintiff. See supra pp. 275-76. It is also not clear that Epstein would even argue for this alternative since he phrases his criticism of the negligence standard as follows: "[T]he general law of negligence does not measure the reasonableness of the plaintiff's conduct by a direct comparison between the two parties to see which is in the better position to avoid the harm." Epstein, supra note 129, at 184. This phraseology suggests that the alternative means to structure the strict liability principle discussed in the text best approximate Epstein's conception. 
change of legal requirements as the underlying practices in an industry change. In the absence of constant statutory revision, allocation of loss according to a position-oriented strict liability principle may reflect a dated efficiency calculation, less attuned to current reality. ${ }^{192}$

Liability on the basis of causation does have intuitive moral appeal. But it is difficult to find the source of this intuition without considering the relative culpability of the actors. Losses will usually occur in the way that could be predicted before the fact using the culpability scale, since the scale accurately reflects the degree of risk posed by the actions of different parties. As a consequence of the high correlation between anterior probability and factual occurrence, liability that is implicitly based on culpability can appear to be liability tied to causation. And the moral underpinning of the culpability scale can mistakenly be claimed as a virtue of a causal rather than fault-based system.

\section{Causation and Efficiency}

Other scholars, principally Steven Shavell ${ }^{193}$ and Guido Calabresi, ${ }^{194}$ have argued that allocating loss according to causation best promotes efficiency. Shavell's assertion appears in his discussion of the advantages of strict liability over negligence, and Calabresi's in his discussion of the proximate cause standard. The gap between my argument and the positions taken by Shavell and Calabresi reduces to the difference between applying foresight as an element of culpability and applying foresight as an element of causation. ${ }^{195}$

Shavell defends strict liability on the ground that allocating loss to the party who is more causally responsible for the loss "serves to maximize social welfare."198 Central to his analysis, then, is his measure of social welfare, which he describes as "the sum of expected utilities; equivalently,

192. See supra note 11 . The problem of dated legislative judgments is somewhat alleviated by the fact that when loss is allocated according to a position-oriented strict liability principle, parties can shift the allocations among themselves. See, e.g., U.C.C. $\$ \S 1-102(3)$ (statement of general principle), 1-204(1) (agreement as to time), 2-303 (agreement as to division as well as allocation of risks). When the parties do so, presumably the bargained-for allocation will refiect the current reality. It is not always practical, however, for parties to bargain about risk allocation. See supra note 119. Moreover, when an agreement between contracting parties affects third parties it is not clear that such agreements are effective. Cf. U.C.C. $\$ \S 3-602$ ("No discharge of any party [to a negotiable instrument] ... is effective against a subsequent holder in due course unless he has notice thereof when he takes the instrument."), 5-106(4) ("Notwithstanding any modification or revocation of a revocable credit any person authorized to honor or negotiate under the terms of the original credit is entitled to reimbursement for or honor of any draft or demand for payment duly honored or negotiated before receipt of notice....").

193. See Shavell, supra note 138; Shavell, Strict Liability Versus Negligence, 9 J. LEGAL STUD. 1 (1980).

194. See Calabresi, supra note 128 .

195. See supra pp. 268-69.

196. Shavell, supra note 138 , at 465 . 
... the sum of benefits parties derive from engaging in their activities minus the costs of exercising care minus expected accident losses and administrative costs."197 Shavell's use of terms such as "expected" reveals that the strict liability gains he identifies are connected to the mens rea of the actor before the event. His scheme thus seems prospective, seeking to deter any behavior that on balance reduces his definition of social welfare. The benefits that Shavell describes as resulting from a system of responsibility connected to causation could therefore just as well be said to result from a system of liability, such as the culpability scale, which is based on the degree of risk. In keeping with this conclusion, Shavell, unlike Epstein, does not maintain that contributory negligence should not be allowed as a defense in an action based on strict liability in tort. ${ }^{198}$

In contrast to Shavell, Calabresi focuses upon the proximate cause standard, arguing that it better serves the compensatory and deterrent goals of the tort system than would but-for causation. For example, with respect to general deterrence, which involves placing "injury costs on those actors who can best decide avoidance is cheaper than bearing those costs,"189 Calabresi notes that "clearly the ability to foresee risks is important in comparing accident avoidance costs with safety costs." ${ }^{200}$ Inasmuch as the culpability scale reflects approximate gradations in the relative abilities of actors to foresee and reduce commercial risks, ${ }^{201}$ Calabresi's insight is useful in understanding the nexus between culpability and responsibility for loss.

To conclude that foreseeability as a component of causation deters loss

197. Id. at 472 .

198. In Strict Liability Versus Negligence, Shavell states as Proposition 1: "Suppose that injurers and victims are strangers. Then strict liability is efficient and is superior to the negligence rule, which is superior to not having liability at all." Shavell, supra note 193, at 12 (emphasis omitted). Although Shavell's Proposition 1 indicates that he too believes that a system based upon strict liability is more efficient than one based upon negligence, his Proposition 4 is as follows:

Suppose that injurers and victims are strangers. Then none of the usual liability rules is efficient. Strict liability with a defense of contributory negligence is superior to the negligence rule if it is sufficiently important to lower injurer activity levels. Strict liability without the defense and no liability are each inferior to whichever rule is better: either strict liability with the defense or the negligence rule.

Id. at 19 (emphasis omitted). Shavell states that even between sellers and customers, when the latter are victims of product defects "the relative performance of liability rules depends on the knowledge customers have about risks." See id. at 20-21 (Propositions 7a, 7b).

It should also be noted that Shavell's introduction of "administrative costs associated with the legal system," see id. at 122, speaks well for responsibility determined according to the culpability scale rather than causation. The factual issues necessary to resolve culpability are relatively narrow compared with the open-endedness of causation, with its various meanings and components.

Posner, too, has concluded that from an efficiency perspective, strict liability with a defense of contributcry negligence is superior to strict liability without the defense. See Posner, Strict Liability, supra note 156, at 221.

199. Calabresi, supra note 128 , at 84 .

200. Id. at 87.

201. See supra p. 268. 
more efficiently than it would as an element inherent in culpability, however, would require the assumption that factors aside from the actor's mens rea systematically affect foreseeability. ${ }^{202}$ Calabresi himself never identifies such factors. ${ }^{203}$ Moreover, this conclusion would further rest on the assumption that factinders such as juries could sort out and weigh mens rea along with other factors under the broad mandate to determine causation as competently as they might determine foreseeability when the actor's state of mind is isolated and categorized by principles of culpability. As we shall see in Part IV, scholars who influenced the Gode's drafters doubted that juries were capable of doing so in a principled manner. ${ }^{204}$

In conclusion, many of the arguments asserted by causal theorists on behalf of the efficiency and morality of a causation-based system of liability depend for their validity upon the overlap between findings of liability according to that system and determinations according to the culpability scale. Where the two approaches lead to different results, those same arguments demonstrate the superiority of the prospective, risk-related orientation of the culpability scale.

\section{The Culpability Scale and the Gode: Coincidence or Design?}

The culpability scale uses a form of risk analysis as the means of allocating responsibility for loss. Such analysis can be traced back to the early twentieth-century realists, who preferred risk analysis as an alternative to loss allocation based on causation. ${ }^{205}$ Karl Llewellyn, the chief reporter of the Uniform Commercial Code, ${ }^{206}$ was the primary spokesman of the re-

202. If we do not make this assumption, proximate cause is simply a confusing misnomer for culpability. See supra p. 268.

203. It should be noted that Calabresi is not arguing the relative efficiency of a proximate cause standard over a culpability standard such as negligence. Rather, he compares the proximate cause standard to a physical test of causation such as the but-for standard. Calabresi, supra note 128.

204. See infra p. 281.

205. The realists did not constitute a distinct school of thought. Rather, the "'movement' consisted of a loosely integrated collection of interacting individuals, with a complex network of personal relationships and an almost equally complex family of related ideas, given some coherence, perhaps, by a shared dissatisfaction . . . with the intellectual milieu of law in general. . . "W. TWINING, supra note 138 , at 26 . The intellectual milieu the realists faced in the early twentieth century was that of "legal formalism," which Morris Cohen described as "mechanical jurisprudence . . . the complacent manipulation of legal concepts in utter disregard of the facts of social life." Cohen, On Absolutisms in Legal Thought, 84 U. PA. L. REV. 681, 681 (1936) (espousing a legal perspective different, however, from most realists); see also Pound, Mechanical Jurisprudence, 8 CoLUM. L. REV. 605 (1908) (originating phrase borrowed by Cohen). Formalism assumed that legal principles could be clearly stated and that the factfinder's activity could be strictly confined to factual determinations.

One example of the formalistic view was that of Professor Joseph Beale of Harvard, who in the context of causation argued, as late as 1920 , that he could "suggest certain more definite principles of law by which the determination of proximity is to be regulated." Beale, supra note 138, at 636. Beale's article was partly a response to critics of the formalistic views of "legal cause" such as Judge Jeremiah Smith. See Smith, supra note 138; infra p. 281.

206. U.C.C. title comment at 3 (Official Draft 1952). 
alist movement; ${ }^{207}$ many of the drafters were influenced by the movement's ideas. Therefore, the presence of the culpability scale within the Code hardly seems coincidental. Although the Code's drafters may not have been fully conscious of the culpability scale as such, they fully understood and supported the instrumentalist perspective that it reflects.

\section{A. The Drafters' Perspective}

The realist attack on causation was anticipated by the publication of a series of articles by Judge Jeremiah Smith ${ }^{208}$ in 1911 and 1912. Smith showed the impossibility of defining legal causation in a way that would permit jurors to apply it in a consistent manner. The result, according to Smith, was uncertainty. Smith consequently advocated that causation be deemphasized by having judges instruct juries simply to determine whether the defendant's tort was "a substantial factor in producing the damage complained of." Although Smith particularly criticized generalizations defining "legal cause in terms of probable consequences," he indicated that probability might play a role when the issue of whether a duty has been violated is addressed. ${ }^{210}$ Smith can thus be said to have foreshadowed the use of risk analysis by the realists.

Two of the first realists to link risk analysis and commercial law explicitly were Underhill Moore and Edwin Patterson. Moore was particularly

207. See W. TwiNiNG, supra note 138, at 70-83. Among Llewellyn's more influential articles were Some Realism About Realism-Responding to Dean Pound, supra note 154, and $A$ Realistic Jurisprudence-The Next Step, 30 CoLUM. L. REV. 431 (1930) [hereinafter cited as Llewellyn, $A$ Realistic Jurisprudence]. For a more recent look at the realist movement, especially as a key component of a broader American intellectual movement toward pragmatic instrumentalism, see Symposium on American Legal Theory, 66 CORNELL L. REV. 861 (1981). In particular, see Summers, Pragmatic Instrumentalism in Twentieth Century American Legal Thought-A Synthesis and Critique of Our Dominant General Theory About Law and Its Use, id. at 861. Professor Summers coins the phrase "pragmatic instrumentalism" to encompass both the realist movement and its intellectual antecedents, the philosophy of Holmes and Pound's sociological jurisprudence, id. at $862-69$, and to emphasize the realists' prospective orientation, see id. at 890,937 . Professor Summers does not, however, focus upon risk analysis as a primary analytic tool of the realists, nor does he seem to accept the possibility that, in much of the law, morality (in his terminology, "norms of right behavior") and efficiency (or an "efficacy" or "consequentialist criterion") might lead to the same legal resolution. See id. at 944-46.

208. Smith, supra note 138.

209. Id. at 309 .

210. Id. at 226, 250. Leon Green later developed Judge Smith's critique of the "proximate cause" standard. See L. GREEN, supra note 138, at 76-77, 132-41, 200. See generally G. WHITE, TORT LAW IN AMERICA 92-102 (1980) (discussing realist attack on traditional legal treatment of causation). In particular, Green's writings were more precise than Smith's about the central role of risk definition and the appropriateness of considering probability of harm. Like Judge Smith, Green advocated a shift away from the element of causation. He argued that "the term 'cause' [should be stripped] of its numerous meanings, leaving it to connote merely the relation between cause and effect-physical causal relation. This is one distinct element of legal liability all by itself, though a minor one." $\mathrm{L}$. GREEN, supra note 138, at 200 (emphasis added). To implement the diminished role that causation should play, Green advocated using Smith's "substantial factor" phraseology when instructing the jury about causation. Id. at 180-85. Note finally that Green thought the focus upon risk definition to be appropriate not only in tort law but also in contract and other commercial settings. Id. at 44-45. 
noted for his work on human behavior; ${ }^{211}$ his study of the behavior of institutions such as banks did much to introduce risk analysis as a basic tool for the realists. ${ }^{212}$ Patterson, a colleague of Llewellyn's at Columbia for twenty-six years, also strongly influenced the realists' use of risk analysis. $^{213}$ In an article written in 1924, ${ }^{214}$ Patterson identified five elements making up "our abstract notion of risk": event, cause, uncertainty, damage, and person of incidence. ${ }^{215}$ It is significant that Patterson did not consider "cause" to be the product of a retrospective finding of a physical relation between an act and the harmful consequence but rather a prospective calculation. Patterson noted that cause in the retrospective sense had generated an enormous amount of litigation. He concluded that the uncertainty surrounding what courts might find to be a cause in this sense-the so-called "juridical risk"-could seriously impair the efficacy of "the legal device as a means of removing uncertainty." 216 The solution he suggested (in the context of insurance contracts) was to eliminate the need to determine whether one phenomenon caused another and, instead, to include foreseeable causes in the definition of the insured-against event. $^{217}$

The environment of legal ideas that formed the realist consensus, then, included disdain for causation as an important legal element, a marked tendency to analyze legal problems in terms of risks, and a generalized concern for the difficulties of the fact-finding process. Jerome Michael ${ }^{218}$

211. Moore described his behaviorist approach to law in Callahan \& Moore, Underhill Moore, in MY PhilosophY OF LaW 203, 203-28 (Julius Rosenthal Found. ed. 1941).

212. In An Institutional Approach to the Law of Commercial Banking, 38 YAL.E L.J. 703 (1929), Moore and coauthor Theodore Hope, Jr., sought to predict judicial decisionmaking in commercial banking cases by the extent to which the institutional patterns observed in the facts of the case deviated from institutional relations in general. Part of Moore's methodology was the conversion of losses into risk terminology. Id. at 718-19. Llewellyn credited Moore, more than any other person, for his awareness of risk analysis. See K. LLEWELLYN, CASES AND MATERIALS ON THE LAW OF SALES at xxiii (1930).

213. For example, Llewellyn identified Patterson as one of 20 realists whose work he had canvassed. See Llewellyn, supra note 154, at 1257-59; see also id. at 1237 (citing Patterson as contributor to the study of relationship between risk-bearing and the law). Llewellyn also acknowledged Patterson's aid and influence in another work. See Llewellyn, On The Complexity of Consideration: A Forward, 41 CoLUM. L. REV. 777, 779 (1941).

214. Patterson, The Apportionment of Business Risks Through Legal Devices, 24 ColuM L. REV. 335 (1924).

215. Id. at 337.

216. Id. at 340 .

217. This suggestion bears significant similarity to Green's contemporaneous advocacy that probability of causing harm be removed as an issue of causation and be considered instead with respect to the state of culpability. See supra note 210 .

218. See W. TWINING, supra note 138, at 424 n.136 (discussing friendship between Llewellyn and Michael). Llewellyn and Michael were on the Columbia Law School faculty between 1927 and 1951. Llewellyn considered Michael to be one of the key realists. See also Llewellyn, On Reading and Using the Newer Jurisprudence, 40 COLUM. L. REV. 581, 605-06 (1940) (discussing some of Michael's works). 
and Herbert Wechsler, ${ }^{219}$ who like Patterson were Llewellyn's colleagues, next added the insight that different states of culpability reflect comparative probabilities that loss will result from the actor's conduct. This thesis was advanced in 1937 in a two-part article entitled A Rationale of the Law of Homicide, ${ }^{220}$ which anticipated the philosophy and methodology of the Model Penal Code. ${ }^{221}$ Michael and Wechsler described and interpreted a culpability scale they found present in the criminal homicide laws of the various states. Three themes emerged, all reflective of the earlier realist literature yet analytically more precise: first, that different states of culpability reflect the varying probabilities that certain events will occur, and more specifically, that the actor's conduct will have its intended effects; ${ }^{222}$ second, that causation-in-fact merits only minor attention in a prescriptive system of criminal law; ${ }^{223}$ and third, that the focus of law should be prospective, that is, its primary goal should be to deter the risk from materializing. ${ }^{24}$ Although Michael and Wechsler were addressing the methodology and goals of criminal law, they also suggested the relevance of this mode of analysis to civil law. ${ }^{225}$

The analyses of realists who shared a common skepticism towards factfinding, especially findings of causation, and who shared an awareness of and interest in risk analysis prospectively oriented towards the goal of deterrence clearly influenced Llewellyn. In concluding Some Realism About Realism, ${ }^{228}$ Llewellyn identified four points of interest that the

219. Wechsler and Llewellyn served on the Columbia Law School faculty together. Both had strong ties to a fellow professor, Jerome Michael. In addition, some evidence exists that Llewellyn gave Wechsler drafts of some of his writings for comments. See Llewellyn, Introduction to J. HaLL, THEFT, LAW AND SOCIETY at Xv n.1 (1935).

220. See Michael \& Wechsler, supra note 106.

221. Wechsler later became the chief reporter of the Model Penal Code. See MOdEL PENAL CODE at iv (Proposed Official Draft 1962).

222. See Michael \& Wechsler, supra note 106, at 721, 742-44.

223. Michael and Wechsler observed in the homicide laws an "effort . . to reduce the scope of liability for results that are unintended and only slightly probable." Id. at 724. "The fact that particular behavior has actually resulted in death," they reasoned, "suffices to establish neither that the behavior is undesirable nor that the person engaging in it is more likely than other men to behave in undesirable ways in the future." Id. at 733 (footnotes omitted).

224. Michael and Wechsler stated:

[I] we are to endeavor to prevent behavior which, when it occurs, actually causes death, we must do so, for the most part, by preventing behavior which is likely to cause death. . . .

[Subject to qualifications,] it can be said that the principal end of the law of homicide is the prevention of behavior which may cause death. Id. at 731 .

225. With respect to their focus upon probability rather than causation, for example, they wrote that "the problem of causality in torts and in criminal law is the same." Id. at 724. Citing Holmes, Michael and Wechsler further noted that in fashioning sanctions to compel reparations in civil law cases, considerations of prevention would be of primary, if not sole, importance. See id. at 745 n.164 (citing O.W. HOLMES, THE COMMON LAW 50 (1881)). Significantly, Michael and Wechsler supported their emphasis of probability and their deemphasis of causation by references to the works of Jeremiah Smith and Leon Green, among others. See id. at 724 n.95.

226. Llewellyn, supra note 154. 
realists shared. One of these was "a strong tendency to approach most legal problems as problems in allocation of risks, and so far as possible, as problems of their reduction, and so to insist on the effects of rules on parties who not only are not in court, but are not fairly represented by the parties who are in court." 227

Llewellyn's Cases and Materials on the Law of Sales illustrates his employment of risk analysis. ${ }^{228}$ In Llewellyn's words, "the book takes up the practices of the laymen who are interested and views the contract as a device for allocating various business risks; it takes up the presumption of Sales law as a device for allocating risks which the parties have not expressly covered."229

Other writings demonstrate Llewellyn's acute awareness that the realists' approach to law was prospective: To him, the primary function of law was to shape the future behavior of people. In fact, the dominant extralegal discipline with which the realists were associated was behaviorism. To Llewellyn, writing as a relatively young scholar in 1930, "it would seem to go without demonstration that the most significant . . . aspects of the relations of law and society lie in the field of behavior, and that words take on importance either because and insofar as they are behavior, or because and insofar as they demonstrably reflect or influence other behavior."230

One can also find evidence in Llewellyn's writings for the moral dimensions of the culpability scale. Even though realism avoided moralistic statements, Llewellyn himself was concerned with the moral dimension and effect of legal rules. ${ }^{231}$ In his discussion of "law-jobs," Llewellyn noted:

The law-jobs are in their bare bones fundamental, they are eternal. Perhaps they can all be summed up in a single formulation: such

227. Id. at 1255. A footnote in the same article is particularly revealing about Llewellyn's admittedly inconsistent employment of risk analysis in his early writings, followed by his consistent application of it thereafter. See id. at 1248 n.67.

228. K. LLEWELLYN, supra note 212 .

229. Id. at $\mathrm{xv}$.

230. Llewellyn, A Realistic Jurisprudence, supra note 207, at 443.

231. This moral streak shines in a number of Llewellyn's activities and writings. Llewellyn, for example, took a very strong position and assumed a very active role in opposing the conviction and execution of Sacco and Vanzetti. See W. TwINING, supra note 138, at 341-49.

232. The concept of "law-jobs" formed a key part of the jurisprudential construct used by Llewellyn and E. Anderson Hoebel, an anthropologist, in studying the law of the Cheyenne Indians. See E. HOEBEL \& K. LLEWELLYN, THE CHEYENNE WAY (1941). For a general discussion of law-jobs, see Llewellyn, The Normative, the Legal, and the Law Jobs: The Problem of Juristic Method, 49 YALE L.J. 1355, 1373 (1940). The law-jobs are the functional roles that law plays in every society to maintain and reorient its "conduct and expectations so as to avoid trouble," to "legitimize action as being authoritative" and to organize "the group or society as a whole so as to provide direction and incentive." Id. The law-jobs' normative function and alignment with legitimate expectations are thus essentially moral in character. See id. at 1387-91. 
arrangement and adjustment of people's behavior that the society (or the group) remains a society (or a group) and gets enough energy unleashed and coordinated to keep on with its job as a society (or a group). . . . [W] hat is being said is that to stay a group, you must manage to deal with centrifugal tendencies, when they break out, and you must manage, preventively, to keep them from breaking out. And that you must effect organization, and that you must keep it effective. $^{233}$

If "selfish pursuits" is substituted for "centrifugal tendencies," Llewellyn's comment tracks our prior discussion of the moral dimension of the culpability scale. ${ }^{234}$

Influences as pervasive as those outlined above should clearly be expected to be present in Llewellyn's work on the Code. Llewellyn, although the primary author of the Code, was not its sole drafter, but the reporters for each of the separate articles worked under his supervision and guidance. ${ }^{235}$

To draft article 3, which would replace the Negotiable Instruments Law, Llewellyn intentionally selected a professor who had taught a course on bills and notes only once before-William Prosser. ${ }^{238}$ Unlike Llewellyn, Prosser, whose area of expertise was torts, was a direct participant in the culpability versus causation debate. ${ }^{237}$ In Handbook of the Law of Torts, ${ }^{238}$ Prosser referred to "proximate cause" as "an unfortunate term" 238 that "only offers obstacles to the determination of the real issue."240 The real issue which proximate cause obscured, according to Prosser, was whether the defendant had actually committed a tort. For

233. Llewellyn, supra note 232 , at 1373 .

234. Llewellyn made a similar point some ten years earlier:

There is, amid the welter of self-serving groups, clamoring and struggling over this machine that will give power over others, and the recurrent emergence of some wholeness, some sense of responsibility which outruns enlightened self-interest, and results in action apparently headed (often purposefully) for the common good. To affirm this . . . merely notes that, lacking such a self-sanation [sic] in terms of the whole, the whole would not indefinitely continue as a whole. And to deny that would be folly.

Llewellyn, A Realistic Jurisprudence, supra note 207, at 461-62.

235. See J. WHITE \& R. SUMMERS, supra note $14, \S 1$, at 3-4.

236. W. TWINING, supra note 138, at 271,460 n. 51 .

237. See W. ProSSER, supra note 138, $\S \S 45-50 ;$ W. PROSSER, SELECTED TOPICS ON THE LAW OF TORTS 191-242 (1954). The publication of the 1941 edition of Prosser's Handbook of the Law of Torts shortly preceded Prosser's work on article 3 and therefore is the best evidence of his perspective on the causation debate at the time. Nor did his views on the subject seem to change during the drafting years, as indicated by the opinions he expressed in the 1955 edition of his handbook. See W. PROSSER, HANDBOOK OF THE LAW OF TORTS, $\$ \$ 47-50,252-282$ (2d ed. 1955). Note also that Prosser was directly influenced in many of his views by Jeremiah Smith and Leon Green. See W. PROSSER, supra note $138, \S 45$, at 313 n.7, 315 n.20, 316 n. 24,318 n. 35,319 n.43, $\S 46$, at 322 n. 59,324 nn.66-67, § 48, at 341 n.56, 343 n.64, $\S 50$, at $373 \&$ nn. $42,44$.

238. W. PROSSER, supra note 138 .

239. Id. § 45 , at 312 .

240. Id. at 314 . 
Prosser, it was critical to deemphasize causation and stress the culpability of the conduct as the crucial factor determining responsibility for the harm. ${ }^{241}$ Causation was simply "a matter of what has in fact occurred."242

Prosser took this approach in drafting article 3. In section 3-406 of the Code, the central negligence section in article 3 , the only nexus required between one's negligence and one's responsibility for an alteration or forgery of an instrument is that the former "substantially contributes" to the latter. ${ }^{243}$ Prosser deliberately substituted the term "substantially contributes" for the more prevalent causal standard, "proximately causes."244

\section{B. Code Language}

The history sketched above clearly suggests that the appearance of the culpability scale in the Code is more than coincidental. Yet if this conclusion is sound, why must the scale be pieced together from various Code sections? Why does the Code not explicitly identify the culpability scale, as does the Model Penal Code? ${ }^{245}$

Of course, the Model Penal Code's culpability scale differs substantially from that of the Uniform Commercial Code. Some of these differences-a narrower definition of negligence; ${ }^{246}$ the inclusion of recklessness as a distinct level of culpability; and the omission of comparative ability to avoid loss at least cost, the basis of the strict liability principle, as a level of culpability-are not difficult to fathom. ${ }^{247}$ Other differences, such as the invisibility of the Uniform Commercial Code's scale as contrasted with the explicitness of that of the Model Penal Code, appear less comprehensible. Both codes were drafted contemporaneously, ${ }^{248}$ and their chief re-

241. Id. at $311-13$

242. Id. $\S 46$, at 321 . Prosser expressed qualified praise for Judge Smith's suggestion that the causation issue be limited to a determination of whether the defendant's conduct was a "substantial factor in producing the damage ...."Id. \&45, at 318 .

243. U.C.C. § 3-406.

244. See id. comment 1. Some, but not all, courts have recognized the deliberateness and significance of the change in terminology. See Dominion Constr., Inc. v. First Nat'l Bank, 271 Md. 154, 162-63, 315 A.2d 69, 73-74 (1974); Thompson Maple Prods. v. Citizens Nat'l Bank, 211 Pa. Super. 42, 234 A.2d 32 (1967).

245. MODEL PENAL CODE $\S 2.02$ (Proposed Official Draft 1962). Tort law manifests a similar culpability scale. See supra note 5 .

246. Not all conduct violative of the U.C.C.'s negligence principle is defined as negligence under the Model Penal Code. Negligence must "involve a gross deviation from the standard of care that a reasonable person would observe in the actor's situation." MODEL PENAL CODE $\S 2.02(2)(d)$ (Proposed Official Draft 1962) (emphasis added).

247. Not every private tort has public consequences; public resources are insufficient to monitor both serious and insignificant tortious conduct; and, in the case of certain torts, sufficient deterrence is probably achieved through the civil liability system. But see Silber, supra note 112 (suggesting that a system of criminal responsibility could be extended beyond its present scope).

248. See U.C.C. title comment at 2-3 (Official Draft 1952) (work began in 1945, was completed in 1952); MODEL PENAL CODE (Tent. Draft No. 1, 1953) (first draft completed in 1953); J. WHITE \& R. SUMMERS, supra note 14, § 1, at 1-6; Mentschikoff, The Uniform Commercial Code: An Ex- 
porters ${ }^{248}$ had close professional and philosophical connections. ${ }^{250}$ These factors would suggest a greater similarity than seems to exist.

At least two reasons might account for this structural difference. ${ }^{251}$ First, the Model Penal Code from its initial stage took the form of a unified statute. The Uniform Commercial Code has many of the trappings of a unified effort, but its unity is often fractured because it functions as the successor to a number of preexisting statutes, each of which was drafted independently. ${ }^{252}$ Indeed, although Llewellyn participated in the Code's drafting and clearly had the greatest influence on its shape and content, the separate reporters for the Code's eight substantive articles, and the committees supporting each reporter, account for the discernably different styles. We have already observed the distinct imprint of William Prosser on article 3. Grant Gilmore, in collaboration with Llewellyn, exerted a similar influence on article 9.253

A second reason that may account for the Code's implicit incorporation of the culpability scale was the opposition among practitioners to a more explicit scheme. The drafters attempted to incorporate a more explicit reference to culpability with respect to the definition of good faith. The definition, proposed in the 1949 draft of the Code, included an objective as well as a subjective standard. ${ }^{254}$ In that form, section 1-203's obligation of good faith would have included the intention, knowledge, and negligence principles. Only strict liability would have remained submerged in individual sections relating to specific risk situations. The 1952 edition of the Code dropped the objective definition of good faith, ${ }^{255}$ reportedly at the

periment in Democracy in Drafting, 36 A.B.A. J. 419 (1950); Schnader, A Short History of the Preparation and Enactment of the Uniform Commercial Code, 22 U. MIAMI L. REV. 1 (1967).

249. The chief reporter of the Model Penal Code was Herbert Wechsler. See AM. LAW INST., MODEL PENAL CODE at iv (Proposed Official Draft 1962). The chief reporter of the Uniform Commercial Code was Karl Llewellyn. U.C.C. title comment at 3 (Official Draft 1952).

250. See supra note 219.

251. Other reasons, in addition to those cited in the text, include the general emphasis upon the "objective test" in commercial law practice at the time the Code was drafted. See W. TWINING, supra note 138, at 216-27. When the Code was drafted, "objective tests" were in vogue, while moral and subjective standards were suspect. In criminal law, however, it is obviously impossible to avoid moral and subjective standards. There was some tendency in criminal law to adopt a deterministic or psychological approach, but this could not be pushed too far without delegitimizing criminal law entirely. See Durham v. United States, 214 F.2d 862, 865-68 (D.C. Cir. 1954), overruled, United States v. Brawner, 471 F.2d 969, 981-83 (D.C. Cir. 1972).

252. See AM. LAW INST., UNIFORM COMMERCIAL CODE at xvi (1978) (among uniform acts that Code superceded were Uniform Warehouse Receipts Act, Uniform Bills of Lading Act, Uniform Stock Transfer Act, Uniform Conditional Sales Act, and Uniform Trust Receipts Act).

253. Gilmore was one of the principal drafters of article 9. See J. WHITE \& R. SUMMERS, supra note $14, \S 1$, at 4 .

254. See U.C.C. § 1-201(16) (Tent. Draft 1949) ("Good faith includes good faith toward all prior parties and observance by a person of the reasonable commercial standards of any business or trade in which he is engaged."); see also id. § 1-203 comments 1, 2 (Tent. Draft 1949) (discussing intended role of "good faith principle" as pervading entire U.C.C.).

255. See id. § 1-201(19) (Official Draft 1952). 
insistence of practitioners associated with the drafting. ${ }^{256}$

At least two traces of an explicit statement of the culpability scale remain. One is the obligation of good faith. ${ }^{257}$ Even without an explicit objective standard, the Code's good faith provision can be read to incorporate not only the intention principle, but also the knowledge principle. Gilmore, at least, seemed to read it that way. ${ }^{258} \mathrm{~A}$ second general statement of the culpability scale appears in section 1-102, which relates to "purposes," "rules of construction," and "variation by agreement." Subsection (3) states:

The effect of provisions of this Act may be varied by agreement, except as otherwise provided in this Act and except that the obligations of good faith, diligence, reasonableness and care prescribed by this Act may not be disclaimed by agreement but the parties may by agreement determine the standards by which the performance of such obligations is to be measured if such standards are not manifestly unreasonable. ${ }^{250}$

This subsection transparently refers to at least two components of the culpability scale: the intention principle, by using the term "good faith," and the negligence principle, by using the terms "reasonableness" and "care." Indeed, "good faith" can be interpreted to refer to the knowledge principle as well, since most conduct violative of the knowledge principle can be described as taken in bad faith. Further, the term "diligence," which the Code does not define, may be a synonym for certain types of conduct, the lack of which would violate the strict liability principle. Besides the reference in section 1-102(3), the term "diligence" is used only six times in the Code. ${ }^{260}$ Each reference is to a situation that might call for positive action. ${ }^{261}$ Because the common law shies away from characterizing instances of nonperformance as negligence, ${ }^{\mathbf{2 6 2}}$ failure to act diligently under the circumstances selected by the Code's authors might not be considered negligent. Yet the actor to whom the obligation is assigned will generally be the party who could act with least cost to avoid loss under the circumstances. For example, the Code defines notice to an organization, such as a

256. See J. WHITE \& R. SUMMERS, supra note $14, \S 14-6$, at 563 ; Gillette, Limitations on the Obligation of Good Faith, 1981 DUKE L.J. 619, 623.

257. U.C.C. \& 1-203.

258. See 2 G. GILMORE, supra note $96, \S 34.2$, at $898-902$.

259. U.C.C. $\S 1-102(3)$ (emphasis added).

260. See id. $\$ \S 1-201(27), 2-705(3)(a), 3-511(1), 4-108(2), 4-503(b), 8-406(1)(a)$.

261. See, e.g., id. $\$ \$ 2-705(3)(a)$ ("To stop delivery the seller must so notify as to enable the bailee by reasonable diligence to prevent delivery of the goods."), 4-108(2) ("Delay by a collecting bank or payor bank . . . is excused if caused by . . . circumstances beyond the control of the bank provided it exercises such diligence as the circumstances require.").

262. See supra note 2 . 
corporation, to be "effective for a particular transaction from the time when it is brought to the attention of the individual conducting that transaction, and in any event from the time when it would have been brought to his attention if the organization had exercised due diligence."28s The Gode continues: "[A]n organization exercises due diligence if it maintains reasonable routines for communicating significant information to the person conducting the transaction and there is reasonable compliance with the routines. ${ }^{3264}$ Whether or not failure by one official in an organization to notify another official of a material fact would constitute legal negligence on the part of the organization, clearly the organization is the least costly purveyor of information once the outside party has communicated that information to anyone within the organization who can appreciate its importance.

As further support for this reading, note that when reference to "diligence" is lacking, section 1-102(3) allows the legislative efficiency judgments underlying the strict liability principle to be modified. ${ }^{285}$ This disposition is consistent with the culpability scale. The cheapest loss avoider in a specific transaction may not be the party that the Code's drafters, based on the positions of the parties, have assumed it to be. The actual parties, therefore, should be able to reallocate the risk, and the savings that result from this reallocation can then be shared. When the parties contract to reallocate the risk of loss, they are not negating the culpability scale, but rather are modifying existing legislative efficiency judgments in line with the underlying culpability scale to fit the facts of their transaction. ${ }^{288}$

In sum, the appearance of a culpability scale in the Code is no mere coincidence. The Code's general pattern of loss allocation reflects the drafters' instrumentalist approach to law. Their focus upon risk reduction made it likely that a strong tendency in the legal culture to assign responsibility according to culpability would be strengthened in the Code.

\section{Conclusion}

One of the major themes of Karl Llewellyn's work was the concept of

263. U.C.C. § 1-201(27).

264. Id.

265. In addition to id. $\S 1-102(3)$, particular provisions in the specific articles underscore the ability of parties to reallocate or divide the risk burden. See, e.g., id. $\$ \S 2-303$ (general provision on allocation or division of risks), 2-509(4) (risk of loss allocable according to wishes of contracting parties).

266. In contrast, application of the intention, knowledge, and negligence principles does not depend upon the facts of individual cases. To allow parties to modify the effect of such principles (as opposed to allowing parties to determine the standard by which such principles are to be applied) would violate the culpability scalc. Accordingly, the Code does not permit such modification. 
"situation sense."267 According to this line of thinking, the context in which commercial actors interact is as important as the rule of law pursuant to which they supposedly act, although Llewellyn did not deny that the rule of law is a component of that context. Llewellyn's concern for the study of specific contexts repeatedly led him to "distrust . . . verbally simple rules." ${ }^{.288}$ It may therefore seem paradoxical or even presumptuous to assert the existence of a culpability scale composed of four elements in a statute whose draftsmanship was directed by a scholar so antagonistic to generalities.

The paradox becomes less acute, however, when we bear in mind that Llewellyn qualified his belief in narrow categories:

The quest for narrower, more significant, categories is always a sound first approach to wide categories which are not giving satisfaction-in-use. But of course, once satisfactory narrower categories have been found and tested, the eternal quest recurs, for wider synthesis-but one which will really stand up in use. ${ }^{268}$

Moreover, the prime subject of Llewellyn's attacks was the use of overly broad doctrine. 270 The culpability scale's principles are not doctrines; more accurately, they pervade doctrines that are specific to particular situations. Nor is the scale settled law from which one can deduce the loss bearer. Indeed, the ultimate irony would be to apply the methodology of the formalists to a document laced with the realists' perspective. Rather, like the realist movement itself, the culpability scale constitutes a tendency in the law. Because the culpability scale is based upon considerations that are themselves deeply rooted in our legal culture, the tendency is sufficiently strong that the commercial lawyer who initially arrives at a conclusion about loss allocation contradictory to the scale would be advised to reread the relevant sections. His initial conclusion will not invariably be wrong, but the risk of mistake will be high. Furthermore, inconsistencies with the culpability scale may presage judicial hostility to the strict application of the Code in the specific instance. In this respect, the commercial culpability scale can be a powerful tool both to understand current commercial law and to identify areas for legislative reform.

267. See K. LLEWELlyN, The COMMON LAW TRADITION 121 (1960).

268. Llewellyn, supra note 154 , at 1237.

269. Id., reprinted with additions in K. LLEWELLYN, supra note 100 , at 56 n.c.

270. See Llewellyn, A Realistic Jurisprudence, supra note 207, at 459-60. 


\section{The Yale Law Journal}

Volume 92, Number 2, December 1982

\section{Richard L. Revesz \\ Editor-in-Chief}

\author{
Steven G. Calabresi \\ Note \& Topics Editor \\ José M. Berrocal \\ Davison M. Douglas \\ Cynthia L. Estlund \\ Carl H. Loewenson, Jr. \\ Note Editors
}

Robert E. Cooper, Jr. Managing Editor

Martha Grace Duncan George Ellard

Michele S. Hirshman Eric L. Lewis

H. J. van der Vaart Article \& Book Review Editors
David E. Brodsky

Sarah Dillian Cohn

Nicholas M. De Feis

Doron A. Henkin

Candice Hoke

C. Bruce Baker

Thomas H. Bell

Michael T. Brady

Troy Brennan

David A. Broadwin

Peter W. Devereaux

Stephen W. DeVine

Joseph A. Franco

Roger George Frey

Nancy I. Greenberg
Michael A. Jacobs

Valerie A. Lambiase

Janet R. Langford

Gene J. Oshman

\section{Senior Editors}

David A. Hansell

Joan E. Hartman

Eugene G. Illovsky

Samuel Issacharoff

Roberta M. Kania

Andrew A. Lance

Gary S. Lawson

Peter B. Marrs

Meridee Moore

Susan R. Necheles

Daniel R. Ortiz
Robert D. Richman

William $\mathrm{H}$. Rooney

Victoria P. Rostow

Don Sparks

Wendy Warring

Linda M. Owens

Wes Parsons

Patrice M. Pitts

Manley W. Roberts

Bennett C. Rushkoff Jeffrey W. Sacks Daniel Smirlock Pat Shapiro Spengler Susan J. Swift

Gene A. Turk, Jr.

Editors

Business Manager: Pamela Standish

Editorial Assistant: Claudia Shapiro

\section{Student Contributors to This Issue}

Joan E. Hartman, Federal and Local Jurisdiction in the District of Columbia

Samuel Issacharoff, Making the Violation Fit the Remedy: The Intent Standard and Equal Protection Law

John K. Setear, Discovery Abuse Under the Federal Rules: Causes and Cures 